Article

\title{
Increasing Polarity in Tacrine and Huprine Derivatives: Potent Anticholinesterase Agents for the Treatment of Myasthenia Gravis
}

\author{
Carles Galdeano ${ }^{1,+} \mathbb{D}$, Nicolas Coquelle ${ }^{2,3,+} \mathbb{D}$, Monika Cieslikiewicz-Bouet ${ }^{4,+}$ (D), \\ Manuela Bartolini ${ }^{5}$ (D), Belén Pérez ${ }^{6}$ (D), M. Victòria Clos ${ }^{6}$ (D), Israel Silman ${ }^{7}$, Ludovic Jean ${ }^{4, *(D),}$ \\ Jacques-Philippe Colletier ${ }^{2, *(\mathbb{D})}$, Pierre-Yves Renard ${ }^{4, *(\mathbb{D})}$ and Diego Muñoz-Torrero ${ }^{1, *(\mathbb{D})}$ \\ 1 Laboratory of Pharmaceutical Chemistry (CSIC Associated Unit), Faculty of Pharmacy and Food Sciences, \\ and Institute of Biomedicine (IBUB), University of Barcelona, Av. Joan XXIII 27-31, E-08028 Barcelona, Spain; \\ cgaldeano@ub.edu \\ 2 Institut de Biologie Structurale, Université Grenoble Alpes, Centre National de la Recherche \\ Scientifique (CNRS)-Commissariat à l'Énergie Atomique (CEA) (UMR 5075), F-38054 Grenoble, France; \\ coquelleni@ill.fr \\ 3 Large-Scale Structures Group, Institut Laue-Langevin, 71 Avenue des Martyrs, 38000 Grenoble, France \\ 4 Laboratory COBRA (UMR 6014), Normandie Université, UNIROUEN, Institut National des Sciences \\ Appliquées (INSA) Rouen, CNRS, 76000 Rouen, France; monika.bouet@gmail.com \\ 5 Department of Pharmacy and Biotechnology, Alma Mater Studiorum University of Bologna, \\ Via Belmeloro 6, I-40126 Bologna, Italy; manuela.bartolini3@unibo.it \\ 6 Department of Pharmacology, Therapeutics and Toxicology, Neuroscience Institute, Autonomous University \\ of Barcelona, E-08193 Barcelona, Spain; belen.perez@uab.cat (B.P.); victoria.clos@uab.cat (M.V.C.) \\ 7 Department of Neurobiology, Weizmann Institute of Science, 76100 Rehovot, Israel; \\ israel.silman@weizmann.ac.il \\ * Correspondence: ludovic.jean@univ-rouen.fr (L.J.); colletier@ibs.fr (J.-P.C.); \\ pierre-yves.renard@univ-rouen.fr (P.-Y.R.); dmunoztorrero@ub.edu (D.M.-T.); \\ Tel.: +33-235522451 (L.J.); +33-457428515 (J.-P.C.); +33-235522476 (P.-Y.R.); +34-934024533 (D.M.-T.) \\ + These authors contributed equally to this study.
}

Received: 9 February 2018; Accepted: 9 March 2018; Published: 11 March 2018

\begin{abstract}
Symptomatic treatment of myasthenia gravis is based on the use of peripherally-acting acetylcholinesterase (AChE) inhibitors that, in some cases, must be discontinued due to the occurrence of a number of side-effects. Thus, new AChE inhibitors are being developed and investigated for their potential use against this disease. Here, we have explored two alternative approaches to get access to peripherally-acting $\mathrm{AChE}$ inhibitors as new agents against myasthenia gravis, by structural modification of the brain permeable anti-Alzheimer AChE inhibitors tacrine, 6-chlorotacrine, and huprine Y. Both quaternization upon methylation of the quinoline nitrogen atom, and tethering of a triazole ring, with, in some cases, the additional incorporation of a polyphenol-like moiety, result in more polar compounds with higher inhibitory activity against human AChE (up to 190-fold) and butyrylcholinesterase (up to 40-fold) than pyridostigmine, the standard drug for symptomatic treatment of myasthenia gravis. The novel compounds are furthermore devoid of brain permeability, thereby emerging as interesting leads against myasthenia gravis.
\end{abstract}

Keywords: acetylcholinesterase inhibitors; butyrylcholinesterase inhibitors; quinolinium compounds; triazoles; structural biology; copper-catalyzed azide-alkyne cycloaddition; click chemistry

\section{Introduction}

Myasthenia gravis is an autoimmune disease that is associated with antibodies directed against nicotinic acetylcholine receptors (AChRs) on the postsynaptic membrane at the neuromuscular junction, 
or against other proteins, such as muscle-specific tyrosine kinase (MuSK), low-density lipoprotein receptor-related protein 4 (LRP4), and agrin, which are involved in AChR clustering on the postsynaptic membrane and in structural maintenance of the neuromuscular synapse [1,2]. Antibodies against AChRs may block these receptors by binding to the acetylcholine-binding site, may reduce the number of available receptors in the membrane by internalization, and may activate the complement cascade, leading to destruction of the postsynaptic muscle membrane and, hence, negatively affecting $\mathrm{AChR}$ function [2,3]. Failure of neuromuscular transmission leads to fluctuating skeletal muscle fatigue and weakness upon repeated contraction, which is the main clinical hallmark of myasthenia gravis. Weakness affects various muscle groups, such as extraocular muscles, which control eye movements, bulbar muscles in the mouth and throat, responsible for speech and swallowing, and limb and axial muscles [1].

The worldwide prevalence of myasthenia gravis has been estimated to be 40-180 per million people, with $10 \%$ being children and adolescents, and an annual incidence of 4-12 per million people, with little geographical variation [1,2,4]. Even though myasthenia gravis remains a rare disease, its incidence and prevalence are increasing, particularly in the elderly [5], likely as a result of improved recognition and diagnosis, due to the widespread availability of autoantibody tests, and of increased life expectancy [4].

Diagnostic testing and symptomatic treatment of myasthenia gravis are based on restoration of cholinergic transmission at the neuromuscular junction by means of peripherally-acting inhibitors of acetylcholinesterase (AChE), the enzyme responsible for the hydrolysis of the neurotransmitter acetylcholine at the synapse [6]. Inhibition of acetylcholine breakdown renders the neurotransmitter more available for nicotinic AChR stimulation, which alleviates muscle weakness by improving neuromuscular transmission [7]. The short-acting AChE inhibitor (AChEI) edrophonium chloride $\left(\right.$ Enlon $^{\circledR}$, Tensilon ${ }^{\circledR}$, Figure 1) is used for diagnosis of myasthenia gravis, because it leads to dramatic amelioration of the functioning of a particularly weak muscle group immediately after administration. Other AChEIs, such as pyridostigmine bromide $\left(\right.$ Mestinon $\left.{ }^{\circledR}\right)$, neostigmine bromide $\left(\operatorname{Prostigmin}^{\circledR}\right)$, and ambenonium dichloride (Mytelase ${ }^{\circledR}$ ) (Figure 1), which were introduced in the early 1950s, are used for the symptomatic treatment of early and mild myasthenia gravis $[3,7,8]$. Patients who do not appropriately respond to symptomatic treatment should be treated with immunosuppressive drugs, which target the underlying pathological immune response, with azathioprine being one of those most widely used [1,2].
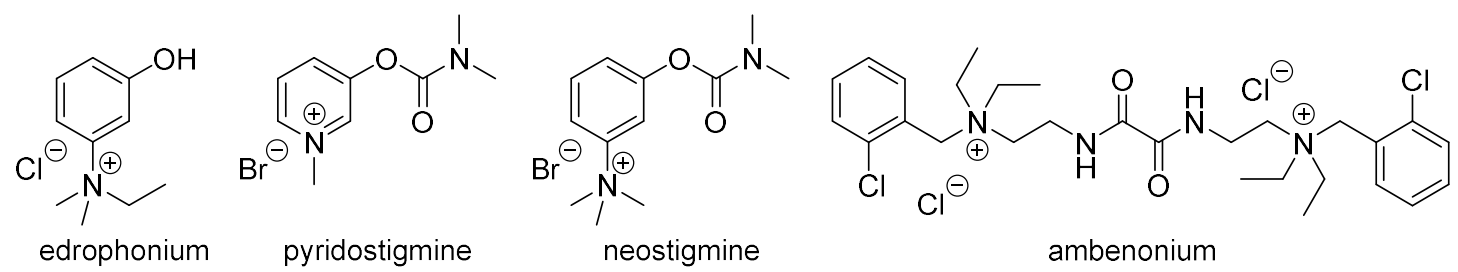

Figure 1. Chemical structures of peripherally-acting AChEIs used for diagnosis and symptomatic treatment of myasthenia gravis.

Commercially available AChEIs often permit patients suffering from myasthenia gravis to function normally, without the need for immunosuppressive drugs. However, their use is accompanied by a number of muscarinic receptor-mediated side-effects, including abdominal cramps, diarrhea, increased gastric and bronchial secretions, salivation, lacrimation, nasal discharge, sweating, increased urination, and bradycardia, which can result in discontinuation of the treatment [7]. Thus, novel AChE inhibitors with more favorable efficacy/safety profiles are being developed for the symptomatic treatment of myasthenia gravis.

To ensure a peripheral effect and prevent blood-brain barrier (BBB) crossing and, hence, potential central cholinergic side-effects, the design of novel AChEIs against myasthenia gravis is 
commonly based on the introduction of permanently charged quaternary nitrogens [9]. A number of alkylammonium [10], piperidinium [11,12], pyridinium [13], quinolinium [14], and isoquinolinium [15] derivatives have been developed as potential drug candidates against myasthenia gravis or as reversal agents of neuromuscular blockade in surgical anesthesia. These compounds usually exhibit AChE inhibitory potencies in the low micromolar to low nanomolar range. It is noteworthy that some of these compounds are formally derived, by quaternization, from centrally-acting AChE inhibitors that are being used for treatment of Alzheimer's disease, such as donepezil [11,12]. Permanently charged derivatives of the anti-Alzheimer drug galantamine have been also reported as potent peripherally-acting AChEIs [16].

Tacrine (1, Scheme 1) was the first AChEI to be approved for treatment of Alzheimer's disease [17]. Its chlorosubstituted derivatives 6-chlorotacrine, 2 [18], and huprine Y, 3 [19-21], are very potent AChEIs that were also developed as candidate drugs against Alzheimer's disease.

In this study, we explored two different approaches to accessing more polar derivatives of tacrine, 6-chlorotacrine, and huprine $Y$, which may serve as new peripherally-acting AChEIs of potential value for treatment of myasthenia gravis. First, we envisaged the classic approach, involving design of permanently charged quinolinium salts (compounds 4-6, Scheme 1). As an alternative approach, we also explored the introduction of non-charged polar moieties attached to a tacrine or 6-chlorotacrine core. To this end, we considered the introduction of a 1,2,3-triazole ring (compounds 9 and 10, Scheme 2). The 1,2,3-triazole ring can be readily installed through the prototypic click reaction, the Huisgen 1,3-dipolar cycloaddition reaction of alkynes and azides [22]. It is a very stable moiety, non-hydrolytically cleavable, essentially non-oxidizable and non-reducible, with a very large dipole moment, and with two out of its three nitrogen atoms able to act as weak hydrogen bond acceptors, so that they can be involved in interactions with biological targets [23]. Indeed, previous studies have highlighted additional favorable interactions of the 1,2,3-triazole group with residues in the AChE active-site gorge, when attached to a tacrine moiety by a two-carbon linker. These additional interactions seem to account for the efficacy of the in situ click chemistry approach (KTGS, kinetic target-guided synthesis) for the synthesis of dual binding-site AChE inhibitors [24-27]. In addition, in some target compounds we decided to introduce a second polar moiety, namely a polyphenol-like moiety at the end of a triazole-containing tether chain (compounds 15 and 16, Scheme 2), with the double purpose of increasing polarity and producing dual site binding to $\mathrm{AChE}$, i.e., simultaneous interaction with both the catalytic anionic site (CAS), at the bottom of the active-site gorge, and with the peripheral anionic site (PAS), at the mouth of the gorge [28], which should result in increased inhibitory potency.

Here we report the synthesis of the above-mentioned novel polar derivatives of tacrine, 6-chlorotacrine, and huprine $Y$, and the in vitro evaluation of their inhibitory activities against human $\mathrm{AChE}(\mathrm{hAChE})$ and human butyrylcholinesterase (hBChE), a second human cholinesterase that hydrolyzes acetylcholine in the blood and in the central nervous system. To assess the peripheral distribution and discard potential central cholinergic effects of these lead compounds, their brain permeability was also assessed in vitro. Furthermore, the three-dimensional structures of complexes of several of these compounds with Torpedo californica AChE (TcAChE) were also solved, in order to shed light on their mechanism of action.

\section{Results and Discussion}

\subsection{Synthesis of the Target Compounds}

The new quinolinium iodide derivatives $\mathbf{4}-\mathbf{6}$ were prepared in good yield by reaction of tacrine, 6-chlorotacrine, and huprine $Y$, respectively, with excess iodomethane in refluxing methyl ethyl ketone [29] (Scheme 1). 


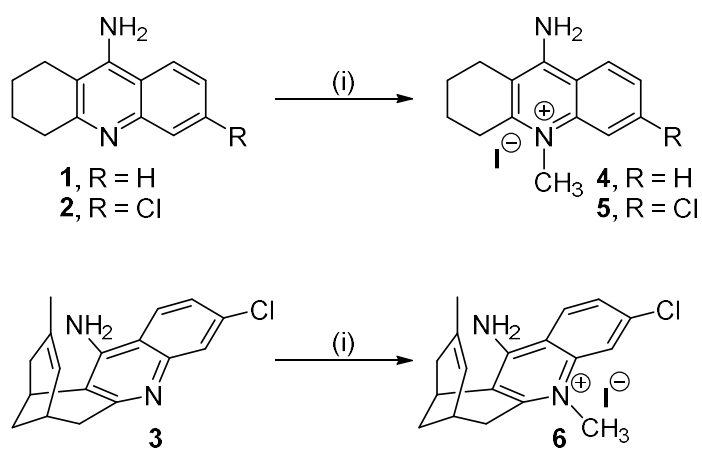

Scheme 1. Synthesis of tacrine-, 6-chlorotacrine-, and huprine-based quinolinium derivatives 4-6. Reagents and conditions: (i) MeI, methyl ethyl ketone, reflux, overnight, 91\% yield (4), 91\% yield (5), $77 \%$ yield (6).

The synthesis of the triazole-based compounds 9, 10, 15, and 16 started from the known azidoalkyltacrines 7 [30] and 8 [31], which, in turn, were readily prepared by reaction of 9-chloro-1,2,3,4-tetrahydroacridine or 6,9-dichloro-1,2,3,4-tetrahydroacridine with 2-aminoethanol, followed by conversion of the resulting hydroxyethyl tacrine derivatives to the corresponding mesylates [32], and a final nucleophilic substitution reaction with sodium azide in acetonitrile at $80{ }^{\circ} \mathrm{C}$. Copper-catalyzed azide-alkyne cycloaddition reaction of azides 7 and 8 with 3-butyn-1-ol afforded the target triazole-containing tacrines $\mathbf{9}$ and $\mathbf{1 0}$ in $63 \%$ and $81 \%$ yield, respectively (Scheme 2).

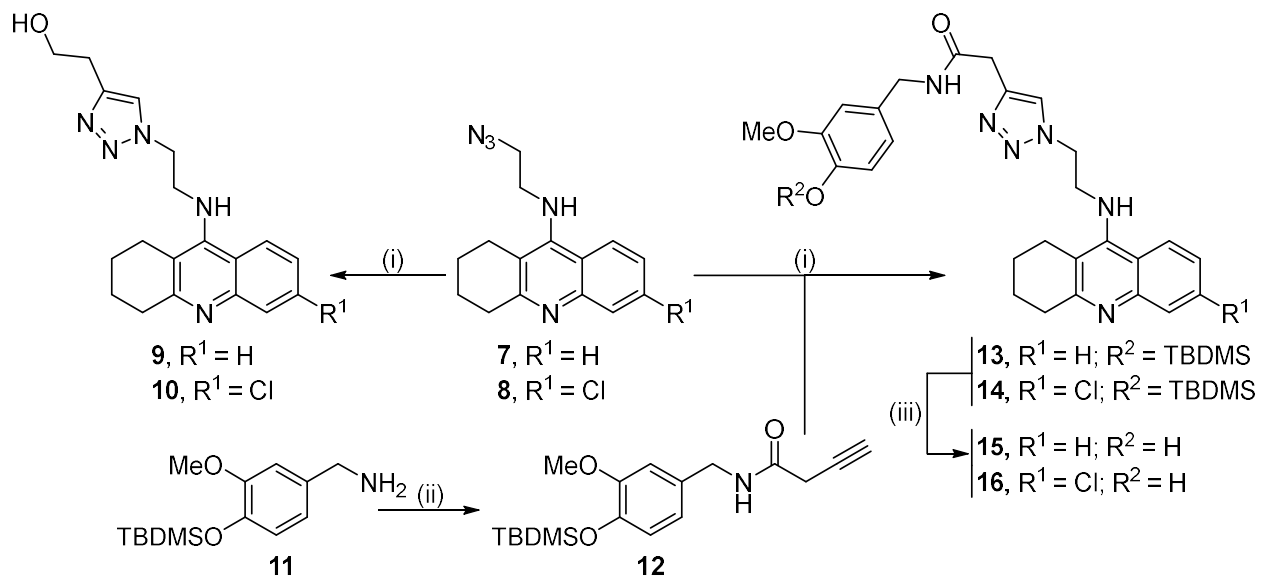

Scheme 2. Synthesis of tacrine-based triazole derivatives 9, 10, 15, and 16. Reagents and conditions: (i) alkyne (3-butyn-1-ol or 12), CuI, acetonitrile, r.t., $16 \mathrm{~h}, 63 \%$ yield (9), 81\% yield (10), 99\% yield (13), $60 \%$ yield (14); (ii) 3-butynoic acid, EDC $\cdot \mathrm{HCl}, \mathrm{CH}_{2} \mathrm{Cl}_{2}$, r.t., $2 \mathrm{~h}, 36 \%$ yield; (iii) $\mathrm{CSA}, \mathrm{MeOH}$, r.t., $18 \mathrm{~h}$ (for $15,15 \%$ yield) or TBAF, THF, $0{ }^{\circ} \mathrm{C}, 1 \mathrm{~h}$, then r.t., $1 \mathrm{~h}$ (for $16,69 \%$ yield).

For the synthesis of the target triazole-based compounds 15 and 16, the new alkyne 12 was first prepared by amide coupling of the know amine 11 [33] with 3-butynoic acid (Scheme 2). Copper(I)-catalyzed Huisgen reaction of alkyne $\mathbf{1 2}$ with azides $\mathbf{7}$ and $\mathbf{8}$ afforded in good yields the $O$-TBDMS-protected triazole intermediates 13 and 14, which were finally converted into the target triazole-containing tacrines $\mathbf{1 5}$ and $\mathbf{1 6}$ upon deprotection with camphorsulfonic acid (CSA) in $\mathrm{MeOH}$ or with tetrabutylammonium fluoride (TBAF) in THF, respectively (Scheme 2).

\subsection{Biological Profiling of the Target Compounds}

The inhibitory activities of the novel compounds against human recombinant AChE and human serum BChE were evaluated using the method by Ellman et al. [34], using as reference compounds 
pyridostigime, the most widely used AChE inhibitor for treatment of myasthenia gravis, and tacrine, 6-chlorotacrine, and huprine $Y$, the apolar brain-permeable parent compounds.

Interestingly, all the novel compounds exhibited hAChE and $\mathrm{hBChE}$ inhibitory potencies in the low micromolar to submicromolar, or even low nanomolar range, with most being more potent than or equipotent to pyridostigmine (Table 1 ).

Table 1. hAChE and hBChE inhibitory activities and PAMPA-BBB permeabilities of the target and reference compounds.

\begin{tabular}{cccc}
\hline Compounds & $\begin{array}{c}\text { hAChE } \\
\mathbf{I C}_{\mathbf{5 0}}(\boldsymbol{\mu M})^{\mathbf{1}}\end{array}$ & $\begin{array}{c}\mathbf{h B C h E} \\
\mathbf{I C}_{\mathbf{5 0}}\left(\boldsymbol{\mu M} \mathbf{~}^{\mathbf{1}}\right.\end{array}$ & $\begin{array}{c}\text { PAMPA-BBB } \\
\mathbf{P e}\left(\mathbf{1 0}^{-\mathbf{6}} \mathbf{c m} / \mathbf{s}\right) \\
\text { (Prediction) }^{\mathbf{2}}\end{array}$ \\
\hline $\mathbf{4}$ & $12.0 \pm 1.00$ & $2.85 \pm 0.19$ & $1.70 \pm 1.50(\mathrm{CNS}-)$ \\
$\mathbf{5}$ & $2.45 \pm 0.28$ & $22.3 \pm 1.50$ & $1.20 \pm 0.80(\mathrm{CNS}-)$ \\
$\mathbf{6}$ & $0.06 \pm 0.01^{3}$ & $3.25 \pm 0.15$ & $10.90 \pm 1.50(\mathrm{CNS}+)$ \\
$\mathbf{9}$ & $1.73 \pm 0.12$ & $0.17 \pm 0.01$ & $0.03 \pm 0.001(\mathrm{CNS}-)$ \\
$\mathbf{1 0}$ & $0.20 \pm 0.01$ & $3.25 \pm 0.17$ & $0.02 \pm 0.001(\mathrm{CNS}-)$ \\
$\mathbf{1 5}$ & $0.25 \pm 0.01$ & $0.05 \pm 0.00^{4}$ & $0.03 \pm 0.001(\mathrm{CNS}-)$ \\
$\mathbf{1 6}$ & $0.01 \pm 0.00^{5}$ & $0.29 \pm 0.01$ & $2.97 \pm 0.61(\mathrm{CNS} \pm)$ \\
pyridostigmine & $1.38 \pm 0.07$ & $2.13 \pm 0.20$ & - \\
tacrine & $0.32 \pm 0.01$ & $0.05 \pm 0.00^{6}$ & - \\
6-chlorotacrine & $0.01 \pm 0.00^{7}$ & $0.50 \pm 0.03$ & $19.8 \pm 0.4(\mathrm{CNS}+)$ \\
huprine Y & 8 & $0.18 \pm 0.01$ & $23.8 \pm 2.7(\mathrm{CNS}+)$ \\
\hline
\end{tabular}

${ }^{1} \mathrm{IC}_{50}$ (half maximal inhibitory concentration) towards human recombinant $\mathrm{AChE}$ and human serum $\mathrm{BChE}$. Values are expressed as mean \pm standard error of the mean (SEM) of at least three experiments, each performed in duplicate; ${ }^{2}$ Permeability values $(P e)$ from the PAMPA-BBB assay and prediction of BBB permeation. Data are the mean of three independent experiments \pm SD. High BBB permeation (CNS+) is expected for compounds with $P e>5.19$, whereas low BBB permeation (CNS-) is expected for compounds with $\mathrm{Pe}<2.07 ;{ }^{3} \mathrm{IC} \mathrm{C}_{50} \mathrm{hAChE}=59.2 \mathrm{nM}( \pm 5.7) ;{ }^{4} \mathrm{IC}_{50} \mathrm{hBChE}=54.8 \mathrm{nM}( \pm 1.6) ;{ }^{5} \mathrm{IC}_{50} \mathrm{hAChE}=7.18 \mathrm{nM}( \pm 0.29)$; ${ }^{6} \mathrm{IC}_{50} \mathrm{hBChE}=45.8 \mathrm{nM}( \pm 3.0) ;{ }^{7} \mathrm{IC}_{50} \mathrm{hAChE}=14.5 \mathrm{nM}( \pm 0.9) ;{ }^{8} \mathrm{IC}_{50} \mathrm{hAChE}=1.07 \mathrm{nM}( \pm 0.05)$.

On the basis of the results obtained, some structure-activity relationships (SAR) can be derived: (i) quaternization of the potent inhibitors tacrine, 6-chlorotacrine, and huprine $Y$ to the quinolinium derivatives 4-6 results in a drop in their inhibitory potency towards both hAChE and hBChE; (ii) the ranking of potencies for the quinolinium derivatives remains the same as that found for the noncharged parent compounds, i.e., huprine derivative $\mathbf{6}>6$-chlorotacrine derivative $5>$ tacrine derivative 4 for hAChE inhibition and tacrine derivative $4>$ huprine derivative $6>6$-chlorotacrine derivative 5 , for $\mathrm{hBChE}$ inhibition, with the well-known contribution of the chlorine atom on the benzene ring of tacrine and huprine derivatives, which is positive for hAChE inhibition [35], and detrimental for $\mathrm{hBChE}$ inhibition [36,37], being retained in the quinolinium derivatives; (iii) introduction of the triazole-containing side chain at position 9 of tacrine and 6-chlorotacrine results in a slight drop in inhibitory activity towards both hAChE and hBChE for compounds 9 and 10; (iv) however, when the triazole-containing side chain is terminated with a polyphenol-like aromatic ring, the resulting compounds, 15 and 16, are slightly more potent $\mathrm{hAChE}$ and $\mathrm{hBChE}$ inhibitors than the parent tacrine and 6-chlorotacrine, likely as a result of multi-site binding within both these cholinesterases; (v) the positive and negative effects of the chlorine atom in the tacrine derivatives on hAChE and hBChE inhibitory activities, respectively, also operates in the triazole series.

Inhibition of $\mathrm{AChE}$ at the neuromuscular junction results in an extended lifetime of the neurotransmitter ACh in the synaptic cleft, which repetitively activates the nicotinic AChRs that, in myasthenia gravis, are affected by autoantibodies. This compensates for the reduction in nicotinic $\mathrm{AChR}$ density, thereby rescuing muscle function. Conversely, inhibition of BChE, which is localized on the surface of terminal Schwann cells, key components of the neuromuscular junction, not only does not have an effect on synaptic ACh lifetime, but depresses ACh release into the synaptic cleft, via activation of $\alpha 7$ nicotinic AChRs, which co-localize with BChE on terminal Schwann cells $[38,39]$. Thus, selective 
inhibitors of AChE are the preferred option for the functional improvement of muscle function in myasthenia gravis, as compared to non-selective inhibitors, for which concomitant inhibition of BChE counteracts the positive effect produced by AChE inhibition. In this context, the huprine and triazole derivatives 6, 10 and 16 are those with the most potent and selective hAChE inhibitory activity, with $\mathrm{IC}_{50}$ values of $59.2 \mathrm{nM}, 200 \mathrm{nM}$ and $7.18 \mathrm{nM}$, respectively, and selectivities for hAChE over hBChE inhibition of 55,16, and 40, respectively. Most important, these compounds are 23-, 7- and 192-fold more potent and 37-, 11- and 27-fold more selective hAChE inhibitors than pyridostigmine, the most widely used drug for treatment of myasthenia gravis and other myasthenic syndromes [40].

To assess whether the two strategies to increase polarity that were used in the design of the target compounds could produce the expected selective peripheral distribution, preventing entry into the central nervous system, we evaluated the brain permeability of these compounds by the widely used in vitro parallel artificial membrane permeability assay for BBB (PAMPA-BBB) [41], using a lipid extract of porcine brain membrane. As expected, the experimentally determined permeability values $(P e)$ of the new polar tacrine and huprine derivatives were, in most cases, in the desired range of low $\mathrm{BBB}$ penetration. The sole exception was the huprine-based quinolinium derivative 6 , which, despite showing a clearly lower Pe value than the parent noncharged compound, huprine $Y$ (Pe 10.90 vs. $23.8\left(10^{-6} \mathrm{~cm} / \mathrm{s}\right)$ ), was nevertheless still in the range of high BBB permeation (Table 1, see also Table 2 for $P e$ values of commercial drugs uses in assay validation).

Even though most of the novel compounds would be expected to display the desired low brain penetration, more thorough physicochemical and pharmacokinetic characterization will be necessary to assess their druglikeness and to address potential ADMET issues, especially in the case of the higher molecular weight compounds $\mathbf{9 , 1 0 , 1 5}$, and 16 [42].

\subsection{Structural Characterization of Complexes of Compounds 5, 6, and $\mathbf{1 6}$ with TcAChE}

To obtain insight into the binding mode of the novel quinolinium and triazole derivatives within the active-site gorge of $\mathrm{AChE}$, these compounds were subjected to co-crystallization trials with TcAChE and structure determination was attempted for the crystalline complexes thus obtained. Crystals were soaked for $12 \mathrm{~h}$ in mother liquor supplemented with a $1 \mathrm{mM}$ solution of the compound. Only the co-crystals obtained with compounds 5, 6 and 16 diffracted satisfactorily, thus permitting solution of their crystal structures. Data collection, structure determination and refinement are further detailed under Materials and Methods (see also Table 3).

In the crystal structure of TcAChE complexed with the 6-chlorotacrine-based quinolinium derivative 5 , we found three molecules of 5 bound to each of the two monomers present in the asymmetric unit. In the active site, the binding mode of 5 is different from that of 6 -chlorotacrine in a hybrid derivative described by Nepovimova et al. (pdb code 4TVK) [43]. While the conjugated system of the molecule is sandwiched between Trp84 and Phe330, making a $\pi$-stacking interaction with Trp84, the orientation of the chlorine atom is quite unusual. Indeed, several crystal structures of acetylcholinesterase with 6-chlorotacrine, or even with the closely related compound, huprine $X$, the 9-ethyl analog of huprine $\mathrm{Y}$ [35], all share a common feature, in which the chlorine atom fits into a hydrophobic groove contributed by Phe330, Tyr334, Trp432, Met437 and Ile439 (see also, below, the complex of TcAChE with the 6-chlorotacrine-based triazole derivative 16). In the TcAChE/5 complex, the chlorine atom faces the opposite side of the gorge, pointing towards the main-chain of residues 116-118 (Figure 2A). To fully validate this new orientation, a Polder map [44], the new generation of the Phenix omit map, was calculated. This map validated our modeling of 5 within the active site of TcAChE, with a $13.2 \sigma$ electron density peak coinciding with the position of the modeled chlorine. In this orientation, the nitrogen of the exocyclic amino group H-bonds to the carbonyl of catalytic His440 (2.73 $\AA$ ), and the methyl group points towards the entrance of the gorge. The loss of the important interactions of the chlorine atom in the above-mentioned hydrophobic pocket is most probably at the origin of the 300-fold drop of potency when compared to 6-chlorotacrine. 
A

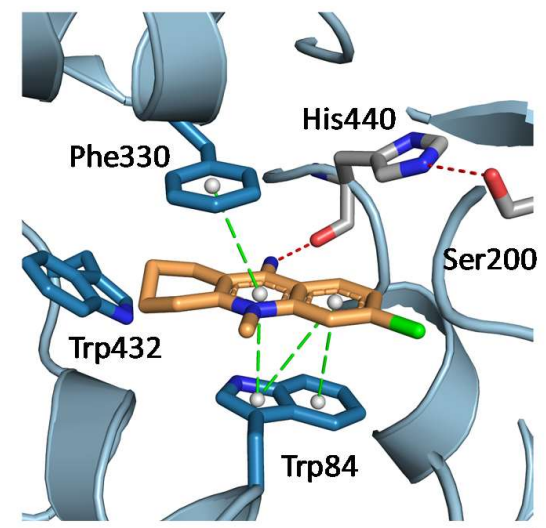

C

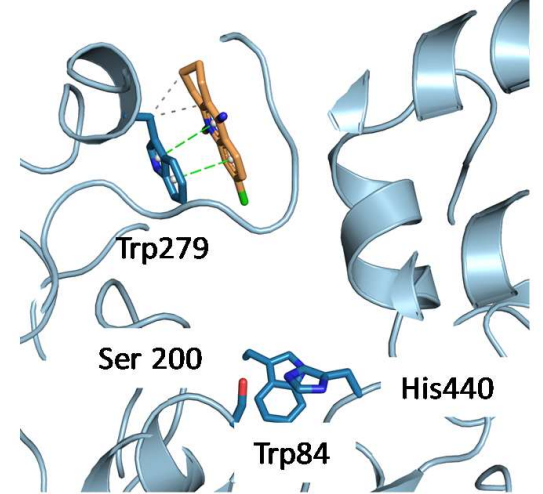

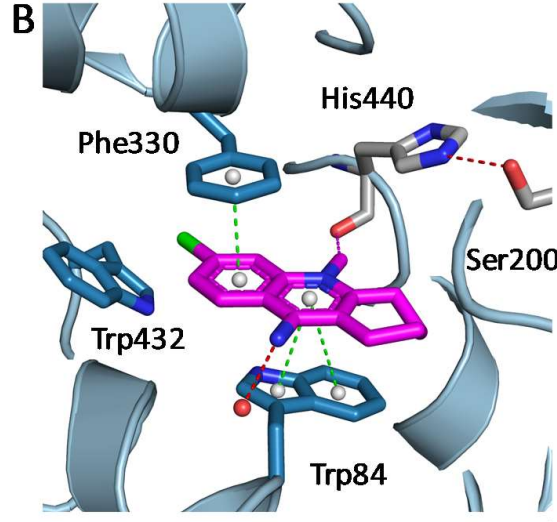

D

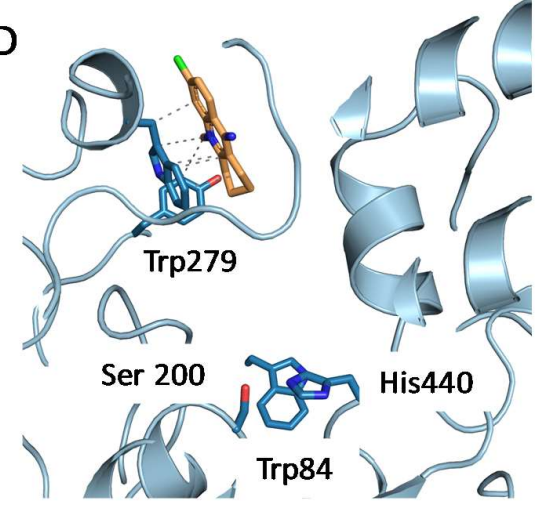

Figure 2. Binding mode of $\mathbf{5}$ within the TcAChE active site (A,B), and at the PAS $(\mathbf{C}, \mathbf{D})$. In the active site, the major pose is represented in (A), with the conjugated system of $5 \pi$-stacked between Phe330 and Trp84. However, the $\mathrm{Cl}$ atom does not point towards Trp432, as usually observed for 6-chlorotacrine derivatives, and the nitrogen of the exocyclic amino group is H-bonded to the carbonyl group of catalytic His440. A minor pose has also been modeled, with the $\mathrm{Cl}$ atom towards the hydrophobic pocket. In this orientation, the methyl group makes close contact $(2.7 \AA)$ with catalytic His 440 , and potentially interacts via a weak H-bond [45]. At the peripheral site, two orientations are also observed, and were refined with identical occupancies (0.5). Hydrophobic interactions are represented as dashed gray lines, $\pi$-stacking interactions are in green, and hydrogen bonds are in red.

A closer inspection of the Polder map revealed a bump in the density that was not satisfactorily modeled with this unique orientation. In the refinement cycles following the addition of 5 in the model, this positive density bump was retained in the mFo-DFc maps. This bump would perfectly fit the position of the $\mathrm{Cl}$ atom in the usual orientation of 6-chlorotacrine within the AChE active site. We decided, therefore, to model a second, minor, orientation in the active site of TcAChE (Figure 2B). In this orientation, the nitrogen atom of the exocyclic amino group is H-bonded to water molecules, while the methyl group faces the main chain of catalytic Ser200 (2.74 $⿱$ ) $)$. This close contact of the methyl group with the protein is probably the reason that this conformation is poorly populated.

Other large electron density blobs in the mFo-DFc maps indicated the presence of a second copy of 5 at the PAS. 5 was modeled, making a $\pi-\pi$ stacking with Trp279, but in two alternate conformations, with the $\mathrm{Cl}$ atom pointing either into or out of the gorge (Figure 2C,D). Finally, a third molecule of 5 was modeled sandwiched between the aforementioned $\mathbf{5}$ molecules at the PAS and a symmetry-related protein molecule of the crystal (Figure 2C). The presence of this third copy of 5 at the PAS thus appears to be a consequence of crystal packing interactions (not shown).

In the crystal structure of TcAChE complexed with the 6-chlorotacrine-based triazole derivative 16, the 6-chlorotacrine moiety binds as previously observed, with the conjugated system $\pi$-stacked to $\operatorname{Trp} 84$, and the $\mathrm{Cl}$ atom fitting into the hydrophobic groove comprising Phe330, Tyr334, Trp432, Met437, and Ile439. Along the linker, the triazole ring is engaged in two perpendicular $\pi$-stacking interactions with 
Tyr334 and Phe300, and in H-bonds with Tyr121 and Asp72. From this point onwards, the observed conformations of the phenolic moiety of $\mathbf{1 6}$ differ in the two TcAChE monomers of the asymmetric unit. In monomer A (Figure 3A), the phenolic moiety makes a $\pi$-stacking interaction with Trp279 in the PAS. In monomer B (Figure 3B), the ether oxygen of the phenolic moiety H-bonds to the main carbonyl of Arg289.
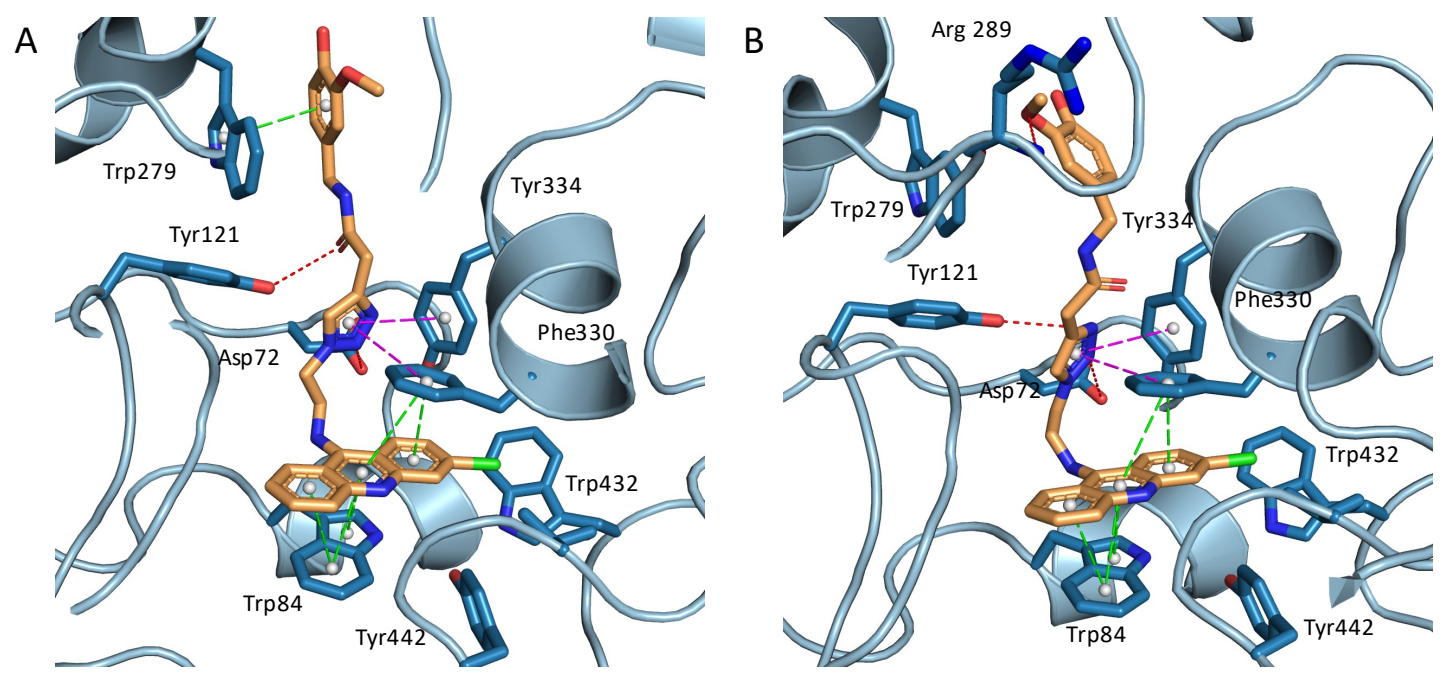

Figure 3. Binding mode of $\mathbf{1 6}$ within the active site of TcAChE in the two copies of the monomer in the asymmetric unit. The binding of the 6-chlorotacrine moiety and of the linker up to the triazole ring are similar. The binding of the phenolic moiety differs. In (A), the phenolic moiety is stabilized via a parallel $\pi$-stacking interaction, and is thus more stable than in monomer B (B), in which only the ether oxygen atom of the phenolic moiety is H-bonded to the main chain nitrogen atom of Arg289. Parallel and perpendicular $\pi$-stacking interactions are shown in green and magenta respectively, while H-bonds are depicted in red.

Finally, the crystal structure of the complex of TcAChE with the huprine-based quinolinium derivative 6 shows that the modified huprine moiety binds at the bottom of the gorge, in the choline-binding pocket, via $\pi$-stacking interactions with both Trp84 and Phe330 (Figure 4), similarly to the parent huprines $\mathrm{W}, \mathrm{X}$ and $\mathrm{Y}[35,46,47]$. However, to accommodate the additional methyl group, the huprine plane is slightly shifted away from the catalytic His440, and upwards towards Phe330. When compared to the previously solved structure of the TcAChE/huprine X complex (pdb code 1e66) [35], the chlorine atom barely moves $(0.3 \AA$, for an overall RMSD of $0.2 \AA$ for 222 superimposed Ca atoms), but the deviation increases up to $0.7 \AA$ at the other extremity of the huprine moiety. The extra methyl group constrains accommodation of the huprine moiety in the active site, resulting in close contact with the carbonyl group of His440 (2.7-2.8 $\AA$ ) and Phe330 (distances of 3.2 and $3.3 \AA$ A observed in the $\pi$-stacking interactions, while the short-range repulsion distance between two carbon atoms is $3.4 \AA$ ). Taken together, these repulsive close contacts, generated by the addition of the methyl group, could account for the 55-fold reduction in inhibitory potency of 6 relative to the parent huprine $Y$. 

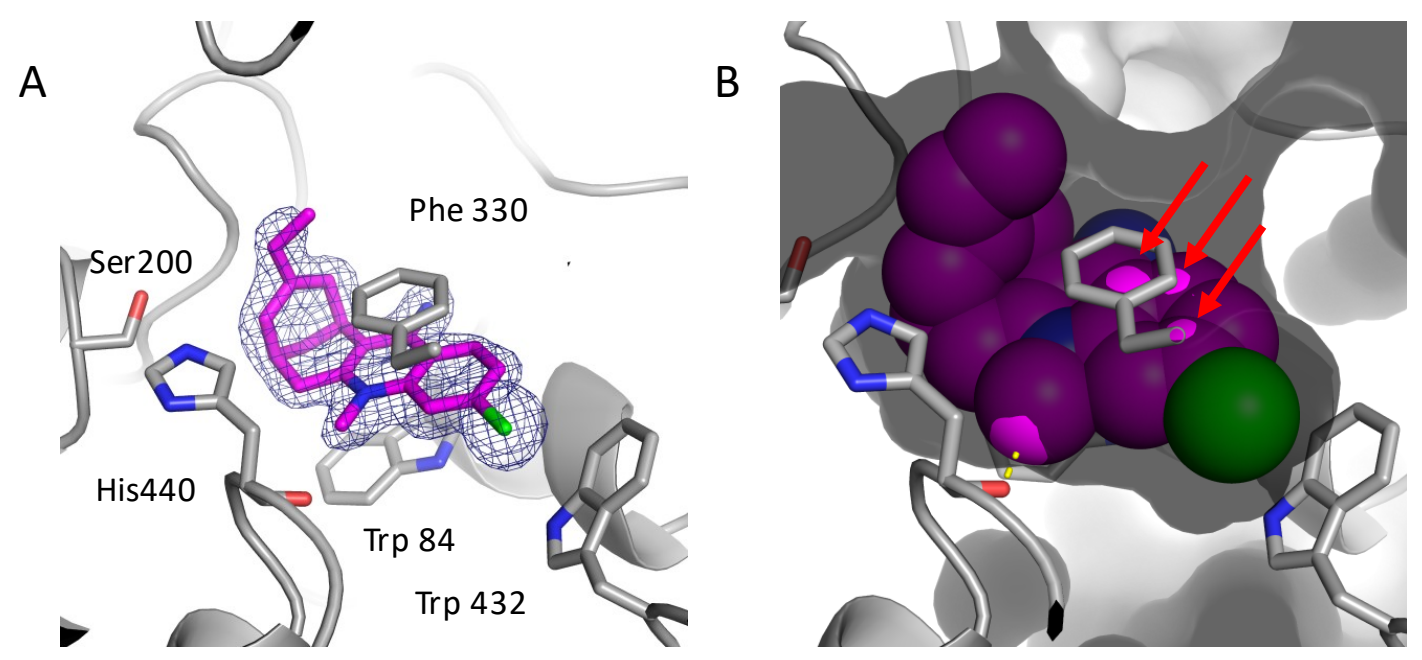

Figure 4. Binding of 6 to TcAChE. (A) $2 \mathrm{mFO}-\mathrm{DF}$ c map, contoured at $1 \sigma$, of 6 within the active site of TcAChE. Clear electron density is observed for the extra methyl group of 6; (B) 6 is depicted in space-filling format, and the gorge surface is shown in gray. A close contact is observed with the carbonyl group of His440 (yellow dashed line). Introduction of the methyl group also resulted in reorientation of some atoms of $\mathbf{6}$ that are in close proximity to Phe330 (red arrows in panel (B)).

\section{Materials and Methods}

\subsection{Chemistry}

\section{General Methods}

Solvents to be used for syntheses were purified with a dry solvent station MB-SPS-800 (MBraun) immediately prior to use. All reagents were obtained from commercial suppliers (Sigma Aldrich (Madrid, Spain; Saint Quentin Fallavier, France), Acros (Belgium), TCI (Japan)) unless otherwise stated, and used without further purification. The reactions were monitored by thin-layer chromatography (TLC) using silica gel (60 F254) plates. Compounds were visualized by UV irradiation and/or spraying with $1 \%$ aqueous $\mathrm{KMnO}_{4}$, followed by charring at $150{ }^{\circ} \mathrm{C}$. Flash column chromatography was performed on silica gel 60 (230-400 mesh, 0.040-0.063 mm) and silica gel 200 (0.060-0.200 mm). Melting points of the new compounds were measured with a MFB 595010M Gallenkamp apparatus. ${ }^{1} \mathrm{H}-\mathrm{NMR}$ (300 or $400 \mathrm{MHz}$ ) and ${ }^{13} \mathrm{C}-\mathrm{NMR}(75$ or $101 \mathrm{MHz}$ ) spectra were recorded on Bruker 300 (Billerica, Massachusetts, MA, USA) or Varian Mercury 400 spectrometers (Palo Alto, California, CA, USA) at the Centres Científics i Tecnològics of the University of Barcelona (CCiTUB) and at the Laboratory COBRA of the University of Rouen; chemical shifts are reported in ppm ( $\delta$ scale) relative to residual solvent signals $\left(\mathrm{CD}_{3} \mathrm{OD}\right.$, DMSO- $d_{6}$ or $\mathrm{CDCl}_{3}$ at 3.31/49.0, 2.50/39.5, or 7.26/77.1 ppm, respectively, in the ${ }^{1} \mathrm{H} /{ }^{13} \mathrm{C}$-NMRspectra) and coupling constants are reported in Hertz $(\mathrm{Hz})$. The syn (anti) notation of the protons at position 13 of the huprine derivative 6 means that the corresponding proton at position 13 is on the same (different) side of the quinoline moiety with respect to the cyclohexene ring. Mass spectra were recorded using the electrospray ionisation technique (ESI). High-resolution mass spectra (HRMS) were obtained with Varian MAT 311 or LC/MSD TOF Agilent Technologies spectrometers, using electrospray analysis. The purity of the novel compounds was determined by analytical HPLC on an Agilent 1100 Series instrument (method A, $\left(\mathrm{NH}_{4}\right)_{2} \mathrm{HPO}_{4} / \mathrm{MeOH} \mathrm{pH} 7.7$, flow rate $1 \mathrm{~mL} / \mathrm{min}$, det. $254 \mathrm{~nm}$ ) or on a Thermo Scientific Surveyor Plus instrument equipped with a PDA detector (method $\mathrm{B}, \mathrm{MeCN} / \mathrm{H}_{2} \mathrm{O} / 0.10 \%$ TFA, flow rate $1 \mathrm{~mL} / \mathrm{min}$, det. 254 and 330 $\mathrm{nm}$ ). Semi-preparative RP-HPLC was performed on a Thermo Scientific SPECTRASYSTEM liquid chromatography system (P4000) equipped with a UV-visible 2000 detector (method C, Varian Kromasil C18 column, $10 \mu \mathrm{m}, 21.2 \mathrm{~mm} \times 250 \mathrm{~mm}$, with MeCN and 0.1\% aq. TFA as eluents, $0 \% \mathrm{MeCN}(5 \mathrm{~min})$, 
followed by linear gradients of $0-30 \%$ (40 $\mathrm{min}$ ), 30-40\% (50 $\mathrm{min}$ ), and $40-80 \%$ (110 $\mathrm{min}$ ) $\mathrm{MeCN}$, at a flow rate of $20.0 \mathrm{~mL} / \mathrm{min}$. Elution profiles were monitored at 250 and $340 \mathrm{~nm}$.

9-Amino-1,2,3,4-tetrahydro-10-methylacridin-10-ium iodide (4). A solution of tacrine, $\mathbf{1}$ (300 mg, $1.51 \mathrm{mmol}$ ), in methyl ethyl ketone $(25 \mathrm{~mL})$ was heated to $80^{\circ} \mathrm{C}$, and then treated dropwise with iodomethane $(6.67 \mathrm{~mL}, 15.2 \mathrm{~g}, 107 \mathrm{mmol})$. The reaction mixture was stirred under reflux overnight and cooled to room temperature. The resulting precipitate was collected by filtration under vacuum and was washed with methyl ethyl ketone $(3 \times 25 \mathrm{~mL})$. The tacrine-based pyridinium derivative 4 ( $465 \mathrm{mg}, 91 \%$ yield $)$ was thus obtained as a white solid: m.p. $>290^{\circ} \mathrm{C}$ (dec); IR (ATR) $v 3319,3185$ (N-H st), 1645, 1619, 1592, 1554, 1532 (ar-C-C, ar-C-N st); ${ }^{1} \mathrm{H}-\mathrm{NMR}\left(400 \mathrm{MHz}, \mathrm{DMSO}-d_{6}\right) \delta 1.75-1.90$ (complex signal, $4 \mathrm{H}, 2-\mathrm{H}_{2}$, 3- $\left.\mathrm{H}_{2}\right), 2.58\left(\mathrm{~m}, 2 \mathrm{H}, 1-\mathrm{H}_{2}\right), 3.09\left(\mathrm{~m}, 2 \mathrm{H}, 4-\mathrm{H}_{2}\right), 3.99\left(\mathrm{~s}, 3 \mathrm{H}, 10-\mathrm{CH}_{3}\right), 7.69(\mathrm{~m}, 1 \mathrm{H}, 7-\mathrm{H}), 7.97(\mathrm{~m}, 1 \mathrm{H}, 6-\mathrm{H})$, $8.16(\mathrm{~d}, J=8.8 \mathrm{~Hz}, 1 \mathrm{H}, 5-\mathrm{H}), 8.42\left(\mathrm{br} \mathrm{s}, 2 \mathrm{H}, 9-\mathrm{NH}_{2}\right), 8.54(\mathrm{~d}, J=8.0 \mathrm{~Hz}, 1 \mathrm{H}, 8-\mathrm{H}) ;{ }^{13} \mathrm{C}-\mathrm{NMR}(101 \mathrm{MHz}$, DMSO-d 6$) \delta 20.3\left(\mathrm{CH}_{2}\right), 21.5\left(\mathrm{CH}_{2}\right), 23.9\left(\mathrm{CH}_{2}\right)(\mathrm{C} 1, \mathrm{C} 2, \mathrm{C} 3), 29.0\left(\mathrm{CH}_{2}, \mathrm{C} 4\right), 35.9\left(\mathrm{CH}_{3}, 10-\mathrm{CH}_{3}\right), 110.8$ (C, C9a), 115.6 (C, C8a), 118.2 (CH, C5), 123.9 (CH), 125.7 (CH) (C7, C8), 133.6 (CH, C6), 138.8 (C, C10a), 154.1 (C), 154.8 (C) (C4a, C9); HRMS (ESI), calculated for $\mathrm{C}_{14} \mathrm{H}_{17} \mathrm{~N}_{2}[\mathrm{M}]^{+}$213.1386, found 213.1339; HPLC purity $99.5 \%\left(t_{R}=15.0\right.$ min, method $\left.\mathrm{A}\right)$.

9-Amino-6-chloro-1,2,3,4-tetrahydro-10-methylacridin-10-ium iodide (5). It was prepared as described for 4. From 6-chlorotacrine, 2 ( $300 \mathrm{mg}, 1.29 \mathrm{mmol})$, the 6-chlorotacrine-based pyridinium derivative 5 (442 $\mathrm{mg}$, 91\% yield) was obtained as a white solid: m.p. $>290{ }^{\circ} \mathrm{C}$ (dec); IR (ATR) $v 3301,3187$ (N-H st), 1642, 1615, 1588, 1553, 1520 (ar-C-C, ar-C-N st); ${ }^{1} \mathrm{H}-\mathrm{NMR}$ (400 MHz, DMSO-d 6 ) $\delta 1.75-1.90$ (complex signal, $\left.4 \mathrm{H}, 2-\mathrm{H}_{2}, 3-\mathrm{H}_{2}\right), 2.55\left(\mathrm{t}, J=6.0 \mathrm{~Hz}, 2 \mathrm{H}, 1-\mathrm{H}_{2}\right), 3.07\left(\mathrm{t}, J=6.0 \mathrm{~Hz}, 2 \mathrm{H}, 4-\mathrm{H}_{2}\right), 3.97\left(\mathrm{~s}, 3 \mathrm{H}, 10-\mathrm{CH}_{3}\right), 7.78$ $\left(\mathrm{dd}, J=9.2 \mathrm{~Hz}, J^{\prime}=2.0 \mathrm{~Hz}, 1 \mathrm{H}, 7-\mathrm{H}\right), 8.15\left(\mathrm{br} \mathrm{s}, 1 \mathrm{H}, 9-\mathrm{NH}_{\mathrm{A}}\right), 8.28(\mathrm{~d}, J=2.0 \mathrm{~Hz}, 1 \mathrm{H}, 5-\mathrm{H}), 8.54(\mathrm{~d}$, $J=9.2 \mathrm{~Hz}, 1 \mathrm{H}, 8-\mathrm{H}), 8.95$ (br s, 1H, 9-NH $\mathrm{BH}){ }^{13} \mathrm{C}-\mathrm{NMR}\left(101 \mathrm{MHz}, \mathrm{DMSO}-d_{6}\right) \delta 20.2\left(\mathrm{CH}_{2}\right), 21.4\left(\mathrm{CH}_{2}\right)$, $23.9\left(\mathrm{CH}_{2}\right)(\mathrm{C} 1, \mathrm{C} 2, \mathrm{C} 3), 29.0\left(\mathrm{CH}_{2}, \mathrm{C} 4\right), 36.3\left(\mathrm{CH}_{3}, 10-\mathrm{CH}_{3}\right), 111.5(\mathrm{C}, \mathrm{C} 9 \mathrm{a}), 114.2(\mathrm{C}, \mathrm{C} 8 \mathrm{a}), 117.9(\mathrm{CH}$, C5), 126.0 (CH), 126.2 (CH) (C7, C8), 138.7 (C), 139.6 (C) (C6, C10a), 154.6 (C), 154.9 (C) (C4a, C9); HRMS (ESI), calculated for $\mathrm{C}_{14} \mathrm{H}_{16}{ }^{35} \mathrm{ClN}_{2}[\mathrm{M}]^{+} 247.0997$, found 247.0999 ; HPLC purity $99.7 \%\left(t_{\mathrm{R}}=17.7 \mathrm{~min}\right.$, method A).

12-Amino-3-chloro-6,7,10,11-tetrahydro-5,9-dimethyl-7,11-methanocycloocta[b]quinolin-5-ium iodide (6). It was prepared as described for 4 . From huprine $\mathrm{Y}, 3(300 \mathrm{mg}, 1.05 \mathrm{mmol})$, the huprine-based pyridinium derivative 6 ( $346 \mathrm{mg}, 77 \%$ yield) was obtained as a white solid: m.p. $283-285^{\circ} \mathrm{C}$ (dec); IR (ATR) v 3314, 3188 (N-H st), 1649, 1611, 1585, 1522 (ar-C-C, ar-C-N st); ${ }^{1} \mathrm{H}-\mathrm{NMR}(400 \mathrm{MHz}$, DMSO- $\left.d_{6}\right) \delta 1.52\left(\mathrm{~s}, 3 \mathrm{H}, 9-\mathrm{CH}_{3}\right), 1.77\left(\mathrm{br} \mathrm{d}, J=12.0 \mathrm{~Hz}, 1 \mathrm{H}, 13-\mathrm{H}_{\text {syn }}\right), 1.87\left(\mathrm{~d}, J=17.6 \mathrm{~Hz}, 1 \mathrm{H}, 10-\mathrm{H}_{\text {endo }}\right)$, superimposed in part $1.86-1.92\left(\mathrm{~m}, 1 \mathrm{H}, 13-\mathrm{H}_{\text {anti }}\right), 2.40\left(\mathrm{dd}, J=17.6 \mathrm{~Hz}, \mathrm{~J}^{\prime}=3.6 \mathrm{~Hz}, 1 \mathrm{H}, 10-\mathrm{H}_{\text {exo }}\right), 2.80$ (br s, $1 \mathrm{H}, 7-\mathrm{H}), 3.03\left(\mathrm{~d}, J=18.0 \mathrm{~Hz}, 1 \mathrm{H}, 6-\mathrm{H}_{\text {endo }}\right), 3.23\left(\mathrm{dd}, J=18.0 \mathrm{~Hz}, J^{\prime}=6.0 \mathrm{~Hz}, 1 \mathrm{H}, 6-\mathrm{H}_{\text {exo }}\right), 3.40$ (br s, $1 \mathrm{H}, 11-\mathrm{H}), 3.97\left(\mathrm{~s}, 3 \mathrm{H}, 5-\mathrm{CH}_{3}\right), 5.50(\mathrm{br} \mathrm{d}, J=5.6 \mathrm{~Hz}, 1 \mathrm{H}, 8-\mathrm{H}), 7.80\left(\mathrm{dd}, J=9.2 \mathrm{~Hz}, J^{\prime}=2.0 \mathrm{~Hz}\right.$, $1 \mathrm{H}, 2-\mathrm{H}), 8.27(\mathrm{~d}, J=2.0 \mathrm{~Hz}, 1 \mathrm{H}, 4-\mathrm{H}), 8.36\left(\mathrm{br} \mathrm{s}, 1 \mathrm{H}, 12-\mathrm{NH}_{\mathrm{A}}\right), 8.58(\mathrm{~d}, J=9.2 \mathrm{~Hz}, 1 \mathrm{H}, 1-\mathrm{H}), 8.94$ (br s, $\left.1 \mathrm{H}, 12-\mathrm{NH}_{\mathrm{B}}\right) ;{ }^{13} \mathrm{C}-\mathrm{NMR}\left(101 \mathrm{MHz}, \mathrm{DMSO}-d_{6}\right) \delta 23.0\left(\mathrm{CH}_{3}, 9-\mathrm{CH}_{3}\right), 26.0(\mathrm{CH}), 26.6(\mathrm{CH})(\mathrm{C} 7, \mathrm{C} 11), 26.7$ $\left(\mathrm{CH}_{2}, \mathrm{C} 13\right), 34.7\left(\mathrm{CH}_{2}\right), 35.7\left(\mathrm{CH}_{2}\right)(\mathrm{C} 6, \mathrm{C} 10), 36.4\left(\mathrm{CH}_{3}, 5-\mathrm{CH}_{3}\right), 114.6(\mathrm{C}), 115.1(\mathrm{C})(\mathrm{C} 11 \mathrm{a}, \mathrm{C} 12 \mathrm{a}), 117.8$ (CH, C4), $124.2(\mathrm{CH}, \mathrm{C} 8), 126.1(\mathrm{CH}), 126.2(\mathrm{CH})(\mathrm{C} 1, \mathrm{C} 2), 132.8$ (C, C9), 138.6 (C, C3), 139.7 (C, C4a), 153.7 (C), 154.1 (C) (C5a, C12); HRMS (ESI), calculated for $\mathrm{C}_{18} \mathrm{H}_{20}{ }^{35} \mathrm{ClN}_{2}$ [M] ${ }^{+} 299.1310$, found 299.1316; HPLC purity $99.7 \%\left(t_{\mathrm{R}}=22.1 \mathrm{~min}\right.$, method $\left.\mathrm{A}\right)$.

2-\{1-[2-(1,2,3,4-Tetrahydroacridin-9-ylamino)ethyl]-1H-1,2,3-triazol-4-yl\}ethanol (9). To a solution of azide 7 $(50 \mathrm{mg}, 187 \mu \mathrm{mol})$ in acetonitrile (HPLC grade, conc $=0.06 \mathrm{M})$, 3-butyn-1-ol $(16 \mathrm{mg}, 224 \mu \mathrm{mol})$ was added via a syringe. The reaction flask was then protected from light, and CuI (36 mg, $187 \mu \mathrm{mol})$ was introduced. The reaction mixture was stirred at room temperature for $16 \mathrm{~h}$. The solvent was evaporated, and the crude product was directly purified by column chromatography (silica gel, $\mathrm{CH}_{2} \mathrm{Cl}_{2} / \mathrm{MeOH}$ mixtures, gradient elution, 100:0 to 95:5, 90:10 and 85:15) to afford the triazole derivative $9(40 \mathrm{mg}, 63 \%$ yield) as an orange-brown oil; $R_{\mathrm{f}}\left(\mathrm{CH}_{2} \mathrm{Cl}_{2} / \mathrm{MeOH} 9: 1\right) 0.53 ;{ }^{1} \mathrm{H}-\mathrm{NMR}\left(300 \mathrm{MHz}, \mathrm{CD}_{3} \mathrm{OD}\right) \delta 1.89-1.91$ $\left(\mathrm{m}, 4 \mathrm{H}\right.$, tacrine $\left.2-\mathrm{H}_{2}, 3-\mathrm{H}_{2}\right), 2.62\left(\mathrm{t}, J=6.0 \mathrm{~Hz}, 2 \mathrm{H}\right.$, tacrine $\left.1-\mathrm{H}_{2}\right), 2.77\left(\mathrm{t}, J=6.9 \mathrm{~Hz}, 2 \mathrm{H}, 2-\mathrm{H}_{2}\right), 2.96$ 
$\left(\mathrm{t}, J=5.7 \mathrm{~Hz}, 2 \mathrm{H}\right.$, tacrine 4- $\left.\mathrm{H}_{2}\right), 3.60\left(\mathrm{t}, J=6.9 \mathrm{~Hz}, 2 \mathrm{H}, 1-\mathrm{H}_{2}\right), 4.15\left(\mathrm{t}, J=5.4 \mathrm{~Hz}, 2 \mathrm{H}, \mathrm{NH}-\mathrm{CH}_{2}-\mathrm{CH}_{2}-\mathrm{N}\right)$, $4.60\left(\mathrm{t}, J=5.4 \mathrm{~Hz}, 2 \mathrm{H}, \mathrm{NH}-\mathrm{CH}_{2}-\mathrm{CH}_{2}-\mathrm{N}\right), 7.41\left(\mathrm{ddd}, J=7.8 \mathrm{~Hz}, J^{\prime}=6.9 \mathrm{~Hz}, J^{\prime \prime}=1.2 \mathrm{~Hz}, 1 \mathrm{H}\right.$, tacrine $7-\mathrm{H}), 7.58(\mathrm{~s}, 1 \mathrm{H}$, triazole $5-\mathrm{H}), 7.62\left(\mathrm{ddd}, J=8.1 \mathrm{~Hz}, J^{\prime}=6.9 \mathrm{~Hz}, J^{\prime \prime}=1.2 \mathrm{~Hz}, 1 \mathrm{H}\right.$, tacrine 6-H), 7.75 $(\mathrm{d}, J=7.8 \mathrm{~Hz}, 1 \mathrm{H}$, tacrine $8-\mathrm{H}), 7.98(\mathrm{~d}, J=8.1 \mathrm{~Hz}, 1 \mathrm{H}$, tacrine $5-\mathrm{H}) ;{ }^{13} \mathrm{C}-\mathrm{NMR}\left(75 \mathrm{MHz}, \mathrm{CD}_{3} \mathrm{OD}\right) \delta 22.9$ $\left(\mathrm{CH}_{2}\right.$, tacrine $\left.\mathrm{C} 2\right)$, $23.6\left(\mathrm{CH}_{2}\right.$, tacrine $\left.\mathrm{C} 3\right)$, $25.7\left(\mathrm{CH}_{2}\right.$, tacrine $\left.\mathrm{C} 1\right), 29.7\left(\mathrm{CH}_{2}, \mathrm{C} 2\right), 32.6\left(\mathrm{CH}_{2}\right.$, tacrine C4), $48.8\left(\mathrm{CH}_{2}, \mathrm{NH}-\mathrm{CH}_{2}-\mathrm{CH}_{2}-\mathrm{N}\right), 51.7\left(\mathrm{CH}_{2}, \mathrm{NH}-\mathrm{CH}_{2}-\mathrm{CH}_{2}-\mathrm{N}\right), 61.9\left(\mathrm{CH}_{2}, \mathrm{C} 1\right), 116.9(\mathrm{C}$, tacrine $\mathrm{C} 9 \mathrm{a})$, $120.1(\mathrm{C}$, tacrine $\mathrm{C} 8 \mathrm{a}), 124.4(\mathrm{CH}$, triazole $\mathrm{C} 5), 124.5(\mathrm{CH}$, tacrine $\mathrm{C} 5), 125.3(\mathrm{CH}$, tacrine $\mathrm{C} 8), 125.8(\mathrm{CH}$, tacrine $\mathrm{C} 7), 131.3(\mathrm{CH}$, tacrine $\mathrm{C} 6), 144.7(\mathrm{C}$, triazole $\mathrm{C} 4), 146.2(\mathrm{C}$, tacrine $10 \mathrm{a}), 154.2(\mathrm{C}$, tacrine $\mathrm{C} 9)$, $157.1\left(\mathrm{C}\right.$, tacrine C4a); MS (ESI+) $338[\mathrm{M}+\mathrm{H}]^{+}$; HRMS (ESI+), calculated for $\mathrm{C}_{19} \mathrm{H}_{24} \mathrm{~N}_{5} \mathrm{O}[\mathrm{M}+\mathrm{H}]^{+}$ 338.1981, found 338.1978; HPLC purity $99.9 \%\left(t_{\mathrm{R}}=17.4 \mathrm{~min}\right.$, method $\left.\mathrm{B}\right)$.

2-\{1-[2-(6-Chloro-1,2,3,4-tetrahydroacridin-9-ylamino)ethyl]-1H-1,2,3-triazol-4-yl\}ethanol (10). It was prepared as described for 9 . From azide $8(40 \mathrm{mg}, 133 \mu \mathrm{mol})$, the triazole derivative $\mathbf{1 0}(40 \mathrm{mg}$, $81 \%$ yield) was obtained as an orange-brown oil; $R_{\mathrm{f}}\left(\mathrm{CH}_{2} \mathrm{Cl}_{2} / \mathrm{MeOH} 9: 1\right) 0.27 ;{ }^{1} \mathrm{H}-\mathrm{NMR}(300 \mathrm{MHz}$, $\left.\mathrm{CD}_{3} \mathrm{OD}\right) \delta 1.89-1.91\left(\mathrm{~m}, 4 \mathrm{H}\right.$, tacrine $\left.2-\mathrm{H}_{2}, 3-\mathrm{H}_{2}\right), 2.61\left(\mathrm{t}, J=6.0 \mathrm{~Hz}, 2 \mathrm{H}\right.$, tacrine $\left.1-\mathrm{H}_{2}\right), 2.74(\mathrm{~m}, 2 \mathrm{H}$, 2- $\left.\mathrm{H}_{2}\right), 2.95\left(\mathrm{t}, J=5.7 \mathrm{~Hz}, 2 \mathrm{H}\right.$, tacrine 4- $\left.\mathrm{H}_{2}\right), 3.65\left(\mathrm{~m}, 2 \mathrm{H}, 1-\mathrm{H}_{2}\right), 4.11\left(\mathrm{t}, J=5.7 \mathrm{~Hz}, 2 \mathrm{H}, \mathrm{NH}-\mathrm{CH}_{2}-\mathrm{CH}_{2}-\mathrm{N}\right)$, $4.59\left(\mathrm{t}, J=5.7 \mathrm{~Hz}, 2 \mathrm{H}, \mathrm{NH}-\mathrm{CH}_{2}-\mathrm{CH}_{2}-\mathrm{N}\right), 7.36\left(\mathrm{dd}, J=9.3 \mathrm{~Hz}, \mathrm{~J}^{\prime}=2.1 \mathrm{~Hz}, 1 \mathrm{H}\right.$, tacrine $\left.7-\mathrm{H}\right), 7.57(\mathrm{~s}, 1 \mathrm{H}$, triazole $5-\mathrm{H}), 7.75(\mathrm{~d}, J=2.1 \mathrm{~Hz}, 1 \mathrm{H}$, tacrine $5-\mathrm{H}), 7.94(\mathrm{~d}, J=9.3 \mathrm{~Hz}, 1 \mathrm{H}$, tacrine $8-\mathrm{H}) ;{ }^{13} \mathrm{C}-\mathrm{NMR}$ (75 MHz, $\left.\mathrm{CD}_{3} \mathrm{OD}\right) \delta 23.0\left(\mathrm{CH}_{2}\right.$, tacrine $\left.\mathrm{C} 2\right)$, $23.6\left(\mathrm{CH}_{2}\right.$, tacrine $\left.\mathrm{C} 3\right), 25.8\left(\mathrm{CH}_{2}\right.$, tacrine $\left.\mathrm{C} 1\right), 29.7\left(\mathrm{CH}_{2}\right.$, C2), $33.3\left(\mathrm{CH}_{2}\right.$, tacrine $\left.\mathrm{C} 4\right), 48.8\left(\mathrm{CH}_{2}, \mathrm{NH}-\mathrm{CH}_{2}-\mathrm{CH}_{2}-\mathrm{N}\right), 51.7\left(\mathrm{CH}_{2}, \mathrm{NH}-\mathrm{CH}_{2}-\mathrm{CH}_{2}-\mathrm{N}\right), 61.9\left(\mathrm{CH}_{2}, \mathrm{C} 1\right)$, $117.7(\mathrm{C}$, tacrine $\mathrm{C} 9 \mathrm{a}), 118.9(\mathrm{C}$, triazole $\mathrm{C} 4), 120.7(\mathrm{C}$, tacrine $\mathrm{C} 8 \mathrm{a}), 124.3(\mathrm{CH}$, triazole $\mathrm{C} 5), 125.1(\mathrm{CH}$, tacrine $\mathrm{C} 5), 125.9(\mathrm{CH}$, tacrine $\mathrm{C} 7), 126.4(\mathrm{CH}$, tacrine $\mathrm{C} 8), 136.6(\mathrm{C}$, tacrine $\mathrm{C} 6), 146.5(\mathrm{C}$, tacrine $10 \mathrm{a})$, 153.4 (C, tacrine C9), $159.2\left(\mathrm{C}\right.$, tacrine C4a); MS (ESI+) $372\left[\mathrm{M}+\mathrm{H}^{+}\right.$; HRMS (ESI+), calculated for $\mathrm{C}_{19} \mathrm{H}_{23}{ }^{35} \mathrm{ClN}{ }_{5} \mathrm{O}[\mathrm{M}+\mathrm{H}]^{+} 372.1591$, found 372.1586; HPLC purity $99.1 \%\left(t_{\mathrm{R}}=17.9\right.$ min, method $\left.\mathrm{B}\right)$.

$\mathrm{N}$-[4-(tert-Butyldimethylsilyloxy)-3-methoxybenzyl]-3-butynamide (12). To a solution of [4-(tertbutyldimethylsilyloxy)-3-methoxyphenyl]methanamine, 11 (2.10 g, $7.85 \mathrm{mmol})$, in dichloromethane (40 mL), 3-butynoic acid $(0.66 \mathrm{~g}, 7.85 \mathrm{mmol})$ and $N$-(3-dimethylaminopropyl)- $N^{\prime}$-ethylcarbodiimide hydrochloride, $\mathrm{EDC} \cdot \mathrm{HCl}(1.18 \mathrm{~g}, 6.16 \mathrm{mmol})$, were successively added. The reaction mixture was stirred at room temperature for $2 \mathrm{~h}$, diluted with water, and extracted with dichloromethane $(2 \times 100 \mathrm{~mL})$. The combined organic phases were washed with water, then with brine, dried over anhydrous $\mathrm{MgSO}_{4}$, and concentrated under reduced pressure. The crude product was purified by flash column chromatography (silica gel, cyclohexane/EtOAc, 80:20 to 70:30) to yield the alkynamide $12(950 \mathrm{mg}, 36 \%$ yield) as a yellow-orange solid. The isomerization allene derivative was also isolated $\left(430 \mathrm{mg}, 16 \%\right.$ yield) as an off-white solid. 12: ${ }^{1} \mathrm{H}-\mathrm{NMR}\left(300 \mathrm{MHz}, \mathrm{CDCl}_{3}\right) \delta 0.14[\mathrm{~s}, 6 \mathrm{H}$, $\left.\mathrm{OSi}\left(\mathrm{CH}_{3}\right)_{2} \mathrm{C}\left(\mathrm{CH}_{3}\right)_{3}\right], 0.98\left[\mathrm{~s}, 9 \mathrm{H}, \mathrm{OSi}\left(\mathrm{CH}_{3}\right)_{2} \mathrm{C}\left(\mathrm{CH}_{3}\right)_{3}\right], 2.33(\mathrm{t}, J=2.7 \mathrm{~Hz}, 1 \mathrm{H}, 4-\mathrm{H}), 3.26(\mathrm{~d}, J=2.7 \mathrm{~Hz}, 2 \mathrm{H}$, 2- $\left.\mathrm{H}_{2}\right), 3.79\left(\mathrm{~s}, 3 \mathrm{H}, 3^{\prime}-\mathrm{OCH}_{3}\right), 4.39\left(\mathrm{~d}, J=5.7 \mathrm{~Hz}, 2 \mathrm{H}, \mathrm{CONHCH}_{2}\right), 6.67-6.85$ (complex signal, $3 \mathrm{H}, 2^{\prime}-\mathrm{H}$, $\left.5^{\prime}-\mathrm{H}, 6^{\prime}-\mathrm{H}\right) ;{ }^{13} \mathrm{C}-\mathrm{NMR}\left(75 \mathrm{MHz}, \mathrm{CDCl}_{3}\right) \delta-4.5\left[2 \mathrm{CH}_{3}, \mathrm{OSi}\left(\mathrm{CH}_{3}\right)_{2} \mathrm{C}\left(\mathrm{CH}_{3}\right)_{3}\right], 18.6\left[\mathrm{C}, \mathrm{OSi}\left(\mathrm{CH}_{3}\right)_{2} \mathrm{C}\left(\mathrm{CH}_{3}\right)_{3}\right]$, $25.8\left[3 \mathrm{CH}_{3}, \mathrm{OSi}\left(\mathrm{CH}_{3}\right)_{2} \mathrm{C}\left(\mathrm{CH}_{3}\right)_{3}\right], 27.5\left(\mathrm{CH}_{2}, \mathrm{C} 2\right), 43.9\left(\mathrm{CH}_{2}, \mathrm{CONHCH}_{2}\right), 55.6\left(\mathrm{CH}_{3}, 3^{\prime}-\mathrm{OCH}_{3}\right), 74.4$ $(\mathrm{CH}, \mathrm{C} 4), 77.5(\mathrm{C}, \mathrm{C} 3), 111.9\left(\mathrm{CH}, \mathrm{C2}{ }^{\prime}\right), 120.2\left(\mathrm{CH}, \mathrm{C} 5^{\prime}\right), 121.0\left(\mathrm{CH}, \mathrm{C6}{ }^{\prime}\right), 131.1\left(\mathrm{C}, \mathrm{C1}^{\prime}\right), 144.7\left(\mathrm{C}, \mathrm{C}^{\prime}\right)$, $151.2\left(\mathrm{C}, \mathrm{C}^{\prime}\right), 166.0(\mathrm{C}, \mathrm{C} 1)$; MS (ESI+) $334[\mathrm{M}+\mathrm{H}]^{+}$.

N-[4-(tert-Butyldimethylsilyloxy)-3-methoxybenzyl]-2-\{1-[2-(1,2,3,4-tetrahydroacridin-9-ylamino)ethyl]-1H-1, 2,3-triazol-4-yl lacetamide (13). It was prepared as described for 9. From azide 7 (40 mg, $150 \mu \mathrm{mol})$, the triazole derivative 13 ( $89 \mathrm{mg}$, $99 \%$ yield) was obtained as a brown oil; $R_{\mathrm{f}}\left(\mathrm{CH}_{2} \mathrm{Cl}_{2} / \mathrm{MeOH}\right.$ 9:1) $0.30 ;{ }^{1} \mathrm{H}-\mathrm{NMR}\left(300 \mathrm{MHz}, \mathrm{CD}_{3} \mathrm{OD}\right) \delta 0.05\left[\mathrm{~s}, 6 \mathrm{H}, \mathrm{OSi}\left(\mathrm{CH}_{3}\right)_{2} \mathrm{C}\left(\mathrm{CH}_{3}\right)_{3}\right], 0.90\left[\mathrm{~s}, 9 \mathrm{H}, \mathrm{OSi}\left(\mathrm{CH}_{3}\right)_{2} \mathrm{C}\left(\mathrm{CH}_{3}\right)_{3}\right]$, 1.65-1.95 (complex signal, $4 \mathrm{H}$, tacrine $\left.2-\mathrm{H}_{2}, 3-\mathrm{H}_{2}\right), 2.59\left(\mathrm{t}, J=6.0 \mathrm{~Hz}, 2 \mathrm{H}\right.$, tacrine 1- $\left.\mathrm{H}_{2}\right), 2.93$ $\left(\mathrm{t}, J=6.0 \mathrm{~Hz}, 2 \mathrm{H}\right.$, tacrine $\left.4-\mathrm{H}_{2}\right), 3.57\left(\mathrm{~s}, 2 \mathrm{H}, 2-\mathrm{H}_{2}\right), 3.72(\mathrm{NH}), 3.77\left(\mathrm{~s}, 3 \mathrm{H}, \mathrm{Ph}-3-\mathrm{OCH}_{3}\right), 4.06(\mathrm{t}, J=5.4 \mathrm{~Hz}$, $\left.2 \mathrm{H}, \mathrm{NH}-\mathrm{CH}_{2}-\mathrm{CH}_{2}-\mathrm{N}\right), 4.24\left(\mathrm{~s}, 2 \mathrm{H}, \mathrm{CONHCH}_{2}\right), 4.60\left(\mathrm{t}, J=5.4 \mathrm{~Hz}, 2 \mathrm{H}, \mathrm{NH}-\mathrm{CH}_{2}-\mathrm{CH}_{2}-\mathrm{N}\right), 6.64-6.75$ (complex signal, 2H, Ph-5-H, Ph-6-H), $6.82(\mathrm{~s}, 1 \mathrm{H}, \mathrm{Ph}-2-\mathrm{H}), 7.37$ (br t, $J=7.5 \mathrm{~Hz}, 1 \mathrm{H}$, tacrine 7-H), 7.58 (br t, $J=7.5 \mathrm{~Hz}, 1 \mathrm{H}$, tacrine 6-H), $7.69(\mathrm{~s}, 1 \mathrm{H}$, triazole $5-\mathrm{H}), 7.74(\mathrm{br} \mathrm{d}, J=8.4 \mathrm{~Hz}, 1 \mathrm{H}$, tacrine $8-\mathrm{H}), 7.90$

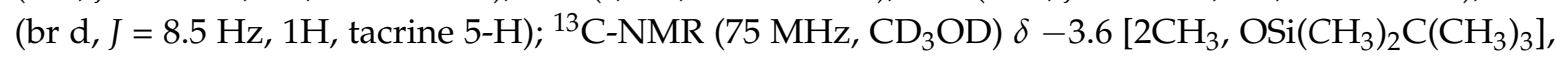


18.8 [C, OSi $\left.\left(\mathrm{CH}_{3}\right)_{2} \mathrm{C}\left(\mathrm{CH}_{3}\right)_{3}\right], 23.1\left(\mathrm{CH}_{2}\right.$, tacrine $\left.\mathrm{C} 2\right), 23.7\left(\mathrm{CH}_{2}\right.$, tacrine $\left.\mathrm{C} 3\right), 25.8\left(\mathrm{CH}_{2}\right.$, tacrine $\left.\mathrm{C} 1\right), 26.2$ $\left[3 \mathrm{CH}_{3}, \mathrm{OSi}\left(\mathrm{CH}_{3}\right)_{2} \mathrm{C}\left(\mathrm{CH}_{3}\right)_{3}\right], 33.1\left(\mathrm{CH}_{2}\right.$, tacrine $\left.\mathrm{C} 4\right), 33.6\left(\mathrm{CH}_{2}, \mathrm{C} 2\right), 44.2\left(\mathrm{CH}_{2}, \mathrm{CONHCH}_{2}\right), 48.8\left(\mathrm{CH}_{2}\right.$, $\left.\mathrm{NH}-\mathrm{CH}_{2}-\mathrm{CH}_{2}-\mathrm{N}\right), 51.7\left(\mathrm{CH}_{2}, \mathrm{NH}-\mathrm{CH}_{2}-\mathrm{CH}_{2}-\mathrm{N}\right), 56.3\left(\mathrm{CH}_{3}, \mathrm{Ph}-3-\mathrm{OCH}_{3}\right), 112.5(\mathrm{CH}, \mathrm{Ph}-\mathrm{C} 2), 116.1(\mathrm{CH}$, Ph-C5), 117.6 (C, tacrine $\mathrm{C} 9 \mathrm{a}), 120.7$ (Ph-C6, tacrine $\mathrm{C} 8 \mathrm{a}), 124.2(\mathrm{CH}$, tacrine $\mathrm{C} 5), 125.4(\mathrm{CH}$, triazole C5), $125.6(\mathrm{CH}$, tacrine $\mathrm{C} 7), 126.4(\mathrm{CH}$, tacrine $\mathrm{C} 8), 130.7(\mathrm{CH}$, tacrine $\mathrm{C} 6), 131.1(\mathrm{C}, \mathrm{Ph}-\mathrm{C} 1), 142.9(\mathrm{C}$, triazole C4), 145.9 (C, Ph-C4), 146.8 (C, tacrine C10a), 148.9 (C, Ph-C3), 153.2 (C, tacrine C9), 158.1 (C, tacrine C4a), $171.4(\mathrm{C}, \mathrm{C} 1)$; MS (ESI+) $601[\mathrm{M}+\mathrm{H}]^{+}$.

N-[4-(tert-Butyldimethylsilyloxy)-3-methoxybenzyl]-2-\{1-[2-(6-chloro-1,2,3,4-tetrahydroacridin-9-ylamino)ethyl] -1H-1,2,3-triazol-4-yllacetamide (14). It was prepared as described for 9. From azide 8 (110 mg, $365 \mu \mathrm{mol})$, the triazole derivative 14 (138 $\mathrm{mg}, 60 \%$ yield) was obtained as a brown oil; $R_{\mathrm{f}}$ (cyclohexane/ AcOEt 6:4) $0.10 ;{ }^{1} \mathrm{H}-\mathrm{NMR}\left(300 \mathrm{MHz}, \mathrm{DMSO}-d_{6}\right) \delta 0.08\left[\mathrm{~s}, 6 \mathrm{H}, \mathrm{OSi}\left(\mathrm{CH}_{3}\right)_{2} \mathrm{C}\left(\mathrm{CH}_{3}\right)_{3}\right], 0.93\left[\mathrm{~s}, 9 \mathrm{H}, \mathrm{OSi}\left(\mathrm{CH}_{3}\right)_{2} \mathrm{C}\left(\mathrm{CH}_{3}\right)_{3}\right]$, 1.78 (complex signal, $4 \mathrm{H}$, tacrine $\left.2-\mathrm{H}_{2}, 3-\mathrm{H}_{2}\right), 2.59\left(\mathrm{t}, J=5.8 \mathrm{~Hz}, 2 \mathrm{H}\right.$, tacrine $\left.1-\mathrm{H}_{2}\right), 2.88\left(\mathrm{br} \mathrm{s}, 2 \mathrm{H}, 2-\mathrm{H}_{2}\right), 3.50$ $\left(\mathrm{m}, 2 \mathrm{H}\right.$, tacrine $\left.4-\mathrm{H}_{2}\right), 3.69\left(\mathrm{~s}, 3 \mathrm{H}, \mathrm{Ph}-3-\mathrm{OCH}_{3}\right), 3.84\left(\mathrm{~m}, 2 \mathrm{H}, \mathrm{NH}-\mathrm{CH}_{2}-\mathrm{CH}_{2}-\mathrm{N}\right), 4.19\left(\mathrm{~s}, 2 \mathrm{H}, \mathrm{CONHCH}_{2}\right)$, $4.54\left(\mathrm{~m}, 2 \mathrm{H}, \mathrm{NH}-\mathrm{CH}_{2}-\mathrm{CH}_{2}-\mathrm{N}\right), 5.75\left(\mathrm{NH}-\mathrm{CH}_{2}-\mathrm{CH}_{2}-\mathrm{N}\right), 6.66$ (complex signal, 2H, Ph-5-H, Ph-6-H), 6.85 (s, $1 \mathrm{H}, \mathrm{Ph}-2-\mathrm{H}), 7.32(\mathrm{~d}, J=9.0 \mathrm{~Hz}, 1 \mathrm{H}$, tacrine 7-H), 7.76-8.03 (complex signal, $3 \mathrm{H}$, triazole $5-\mathrm{H}$, tacrine

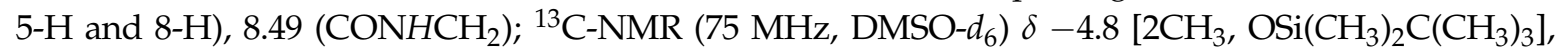
18.1 [C, OSi $\left.\left(\mathrm{CH}_{3}\right)_{2} \mathrm{C}\left(\mathrm{CH}_{3}\right)_{3}\right], 22.0\left(\mathrm{CH}_{2}\right.$, tacrine $\left.\mathrm{C} 2\right), 22.3\left(\mathrm{CH}_{2}\right.$, tacrine $\left.\mathrm{C} 3\right), 24.7\left(\mathrm{CH}_{2}\right.$, tacrine $\left.\mathrm{C} 4\right), 25.5$ $\left[3 \mathrm{CH}_{3}, \mathrm{OSi}\left(\mathrm{CH}_{3}\right)_{2} \mathrm{C}\left(\mathrm{CH}_{3}\right)_{3}\right], 32.7\left(\mathrm{CH}_{2}, \mathrm{C} 2\right), 33.2\left(\mathrm{CH}_{2}\right.$, tacrine $\left.\mathrm{C} 1\right), 40.2\left(\mathrm{CH}_{2}, \mathrm{NH}-\mathrm{CH}_{2}-\mathrm{CH}_{2}-\mathrm{N}\right), 47.6$ $\left(\mathrm{CH}_{2}, \mathrm{NH}-\mathrm{CH}_{2}-\mathrm{CH}_{2}-\mathrm{N}\right), 49.6\left(\mathrm{CH}_{2}, \mathrm{CONHCH}_{2}\right), 55.2\left(\mathrm{CH}_{3}, \mathrm{Ph}-3-\mathrm{OCH}_{3}\right), 111.5(\mathrm{CH}, \mathrm{Ph}-\mathrm{C} 2), 117.1$ (C, tacrine C9a), 118.7 (C, triazole C4), 119.3 (C, tacrine C8a), 119.4 (CH, Ph-C5), 120.1 (CH, Ph-C6), 123.8 $(2 \mathrm{CH}$, tacrine $\mathrm{C} 7$, triazole $\mathrm{C} 5), 125.2(\mathrm{CH}$, tacrine $\mathrm{C} 8), 126.3(\mathrm{CH}$, tacrine $\mathrm{C} 5), 132.7(\mathrm{C}, \mathrm{Ph}-\mathrm{C} 1), 132.9$ (C, tacrine C-6), 147.1 (C, Ph-C4), 149.9 (C, tacrine C10a), 150.3 (C, Ph-C3), 152.4 (C, tacrine C9), 159.3 (C, tacrine C4a), 168.8 (C, C1); MS (ESI+) $635[\mathrm{M}]^{+}$.

N-[4-(hydroxy)-3-methoxybenzyl]-2-\{1-[2-(1,2,3,4-tetrahydroacridin-9-ylamino)ethyl]-1H-1,2,3-triazol-4yljacetamide (15). Camphorsulfonic acid (34 mg, $146 \mu \mathrm{mol}$ ) was added to a solution of the TBDMS-protected triazole derivative $13(89 \mathrm{mg}, 148 \mu \mathrm{mol})$ in $\mathrm{MeOH}(5 \mathrm{~mL})$, and the reaction mixture was stirred at room temperature for $18 \mathrm{~h}$. The solvent was evaporated at reduced pressure, and the crude product was directly purified by column chromatography (silica gel, AcOEt/MeOH mixtures, gradient elution, from 100:0 to 90:10, 80:20 and 50:50), to afford impure triazole derivative 15 . After re-purification by RP-HPLC (Kromasil, $\mathrm{MeCN} / \mathrm{H}_{2} \mathrm{O}(0.1 \% \mathrm{TFA}), 40 \mathrm{~min}$, gradient method C), compound 15 (11 mg, 15\% yield) was obtained as a light brown solid; $R_{\mathrm{f}}(\mathrm{AcOEt} / \mathrm{MeOH} 1: 1)$ 0.63; ${ }^{1} \mathrm{H}-\mathrm{NMR}\left(300 \mathrm{MHz}, \mathrm{CD}_{3} \mathrm{OD}\right) \delta 1.92-2.05$ (complex signal, $4 \mathrm{H}$, tacrine $\left.2-\mathrm{H}_{2}, 3-\mathrm{H}_{2}\right), 2.62(\mathrm{~m}, 2 \mathrm{H}$, tacrine 1- $\left.\mathrm{H}_{2}\right), 3.01\left(\mathrm{~m}, 2 \mathrm{H}\right.$, tacrine $\left.4-\mathrm{H}_{2}\right), 3.56\left(\mathrm{~s}, 2 \mathrm{H}, 2-\mathrm{H}_{2}\right), 3.84\left(\mathrm{~s}, 3 \mathrm{H}, \mathrm{Ph}-3-\mathrm{OCH}_{3}\right), 4.28\left(\mathrm{~s}, 2 \mathrm{H}, \mathrm{CONHCH}_{2}\right)$, $4.45\left(\mathrm{t}, J=5.7 \mathrm{~Hz}, 2 \mathrm{H}, \mathrm{NH}-\mathrm{CH}_{2}-\mathrm{CH}_{2}-\mathrm{N}\right), 4.77\left(\mathrm{t}, J=5.7 \mathrm{~Hz}, 2 \mathrm{H}, \mathrm{NH}-\mathrm{CH}_{2}-\mathrm{CH}_{2}-\mathrm{N}\right), 6.72$ (complex signal, 2H, Ph-5-H, Ph-6-H), 6.85 (s, 1H, Ph-2-H), 7.58 (m, 1H, tacrine 7-H), 7.76-7.89 (complex signal, 3H, triazole $5-\mathrm{H}$, tacrine $5-\mathrm{H}$ and $6-\mathrm{H}), 8.27(\mathrm{~d}, J=9.0 \mathrm{~Hz}, 1 \mathrm{H}$, tacrine $8-\mathrm{H}) ;{ }^{13} \mathrm{C}-\mathrm{NMR}\left(75 \mathrm{MHz}, \mathrm{DMSO}-d_{6}\right)$ $\delta 21.7\left(\mathrm{CH}_{2}\right.$, tacrine $\left.\mathrm{C} 2\right), 22.8\left(\mathrm{CH}_{2}\right.$, tacrine $\left.\mathrm{C} 3\right), 24.9\left(\mathrm{CH}_{2}\right.$, tacrine $\left.\mathrm{C} 4\right), 29.4\left(\mathrm{CH}_{2}\right.$, tacrine $\left.\mathrm{C} 1\right), 33.0$ $\left(\mathrm{CH}_{2}, \mathrm{C} 2\right), 44.2\left(\mathrm{CH}_{2}, \mathrm{CONHCH}{ }_{2}\right), 48.5\left(\mathrm{CH}_{2}, \mathrm{NH}-\mathrm{CH}_{2}-\mathrm{CH}_{2}-\mathrm{N}\right), 51.1\left(\mathrm{CH}_{2}, \mathrm{NH}-\mathrm{CH}_{2}-\mathrm{CH}_{2}-\mathrm{N}\right), 56.4$ $\left(\mathrm{CH}_{3}, \mathrm{Ph}-3-\mathrm{OCH}_{3}\right), 112.4(\mathrm{CH}, \mathrm{Ph}-\mathrm{C} 2), 114.4(\mathrm{C}$, tacrine $\mathrm{C} 9 \mathrm{a}), 116.1(\mathrm{CH}, \mathrm{Ph}-\mathrm{C} 5), 117.6(\mathrm{C}$, tacrine $\mathrm{C} 8 \mathrm{a})$, $120.2(\mathrm{CH}$, tacrine $\mathrm{C} 8), 121.3(\mathrm{CH}, \mathrm{Ph}-\mathrm{C} 6), 125.5(\mathrm{CH}$, triazole $\mathrm{C} 5), 125.9(\mathrm{CH}$, tacrine $\mathrm{C} 7), 126.9$ (2CH, tacrine $\mathrm{C} 5$ and C6), 131.1 (C, triazole C4), 134.2 (C, Ph-C1), 139.4 (C, Ph-C4), 146.9 (C, Ph-C3), 149.0 (C, tacrine 10a), 152.7 (C, tacrine C9), 158.8 (C, tacrine C4a), 180.1 (C, C1); MS (ESI+) 487 [M] ; HRMS (ESI+), calculated for $\mathrm{C}_{27} \mathrm{H}_{31} \mathrm{~N}_{6} \mathrm{O}_{3}[\mathrm{M}+\mathrm{H}]^{+} 487.2458$, found 487.2455; HPLC purity $98.8 \%$ $\left(t_{\mathrm{R}}=20.6 \mathrm{~min}\right.$, method $\left.\mathrm{B}\right)$.

2-\{1-[2-(6-Chloro-1,2,3,4-tetrahydroacridin-9-ylamino)ethyl]-1H-1,2,3-triazol-4-yl\}-N-[4-(hydroxy)-3methoxybenzyl]acetamide (16). A solution of the TBDMS-protected triazole derivative $14(114 \mathrm{mg}$, $179 \mu \mathrm{mol})$ in anhydrous THF $(1.8 \mathrm{~mL})$ was cooled to $0{ }^{\circ} \mathrm{C}$, and then treated dropwise with TBAF $(0.10 \mathrm{~mL}, 120 \mu \mathrm{mol})$. The reaction mixture was stirred at $0{ }^{\circ} \mathrm{C}$ for $1 \mathrm{~h}$ and at room temperature for an additional $1 \mathrm{~h}$. To the resulting mixture AcOEt $(15 \mathrm{~mL})$ and $10 \%$ aqueous $\mathrm{Na}_{2} \mathrm{CO}_{3}$ were 
added. The phases were separated, and the aqueous phase was extracted with AcOEt/THF. The combined organic extracts were dried over anhydrous $\mathrm{Na}_{2} \mathrm{SO}_{4}$, and concentrated at reduced pressure. Purification of the crude product by column chromatography (silica gel, EtOAc/MeOH mixtures, gradient elution, from 100:0 to $90.10,80: 20$, and 50:50) afforded the triazole derivative 16 (64 mg, 69\% yield) as a green-brown oil; $R_{\mathrm{f}}(\mathrm{AcOEt} / \mathrm{MeOH} 1: 1) 0.63 ;{ }^{1} \mathrm{H}-\mathrm{NMR}\left(300 \mathrm{MHz}, \mathrm{CD}_{3} \mathrm{OD}\right)$ $\delta$ 1.82-1.90 (complex signal, $4 \mathrm{H}$, tacrine $\left.2-\mathrm{H}_{2}, 3-\mathrm{H}_{2}\right), 2.55\left(\mathrm{~m}, 2 \mathrm{H}\right.$, tacrine $\left.1-\mathrm{H}_{2}\right), 2.89(\mathrm{~m}, 2 \mathrm{H}$, tacrine $\left.4-\mathrm{H}_{2}\right), 3.58\left(\mathrm{~s}, 2 \mathrm{H}, 2-\mathrm{H}_{2}\right), 3.77\left(\mathrm{~s}, 3 \mathrm{H}, \mathrm{Ph}-3-\mathrm{OCH}_{3}\right), 4.06\left(\mathrm{t}, J=5.4 \mathrm{~Hz}, 2 \mathrm{H}, \mathrm{NH}-\mathrm{CH}_{2}-\mathrm{CH}_{2}-\mathrm{N}\right), 4.24(\mathrm{~s}, 2 \mathrm{H}$, $\left.\mathrm{CONHCH}_{2}\right), 4.59\left(\mathrm{t}, J=5.4 \mathrm{~Hz}, 2 \mathrm{H}, \mathrm{NH}-\mathrm{CH}_{2}-\mathrm{CH}_{2}-\mathrm{N}\right.$ ), 6.68 (complex signal, 2H, Ph-5-H, Ph-6-H), 6.81 $(\mathrm{s}, 1 \mathrm{H}, \mathrm{Ph}-2-\mathrm{H}), 7.29\left(\mathrm{dd}, J=9.0 \mathrm{~Hz}, J^{\prime}=1.5 \mathrm{~Hz}, 1 \mathrm{H}\right.$, tacrine $\left.7-\mathrm{H}\right), 7.68(\mathrm{br} \mathrm{s}, 1 \mathrm{H}$, tacrine $5-\mathrm{H}), 7.74(\mathrm{~s}, 1 \mathrm{H}$, triazole $5-\mathrm{H}), 7.85(\mathrm{~d}, J=9.0 \mathrm{~Hz}, 1 \mathrm{H}$, tacrine $8-\mathrm{H}) ;{ }^{13} \mathrm{C}-\mathrm{NMR}\left(75 \mathrm{MHz}\right.$, DMSO- $\left.d_{6}\right) \delta 22.9\left(\mathrm{CH}_{2}\right.$, tacrine C2), $23.5\left(\mathrm{CH}_{2}\right.$, tacrine $\left.\mathrm{C} 3\right), 24.8\left(\mathrm{CH}_{2}\right.$, tacrine $\left.\mathrm{C} 4\right)$, $25.7\left(\mathrm{CH}_{2}\right.$, tacrine $\left.\mathrm{C} 1\right), 33.0\left(\mathrm{CH}_{2}, \mathrm{C} 2\right), 33.6\left(\mathrm{CH}_{2}\right.$, $\left.\mathrm{CONHCH}_{2}\right), 44.2\left(\mathrm{CH}_{2}, \mathrm{NH}-\mathrm{CH}_{2}-\mathrm{CH}_{2}-\mathrm{N}\right), 51.6\left(\mathrm{CH}_{2}, \mathrm{NH}-\mathrm{CH}_{2}-\mathrm{CH}_{2}-\mathrm{N}\right), 56.4\left(\mathrm{CH}_{3}, \mathrm{Ph}-3-\mathrm{OCH}_{3}\right), 112.4$ (CH, Ph-C2), 116.1 (CH, Ph-C5), 117.5 (C, tacrine C8a), 118.8 (C, tacrine C9a), $121.3(\mathrm{CH}, \mathrm{Ph}-\mathrm{C} 6), 124.8$ $(2 \mathrm{CH}$, triazole $\mathrm{C} 5$, tacrine $\mathrm{C} 7), 126.0(\mathrm{CH}$, tacrine $\mathrm{C} 8), 126.5(\mathrm{CH}$, tacrine $\mathrm{C} 5), 131.1(\mathrm{C}$, triazole $\mathrm{C} 4)$, 133.5 (C, Ph-C1), 136.6 (C, tacrine C6), 146.1 (C, Ph-C4), 146.8 (C, Ph-C3), 148.9 (C, tacrine 10a), 153.6 (C, tacrine C9), 158.8 (C, tacrine C4a), 171.4 (C, C1); MS (ESI+) $521[\mathrm{M}]^{+}$; HRMS (ESI+), calculated for $\mathrm{C}_{27} \mathrm{H}_{30}{ }^{35} \mathrm{ClN}_{6} \mathrm{O}_{3}[\mathrm{M}+\mathrm{H}]^{+}$521.2068, found 521.2072; HPLC purity $95.9 \%\left(t_{\mathrm{R}}=20.6\right.$ min, method B).

\subsection{Biological Profiling}

\subsubsection{Evaluation of $h A C h E$ and $h B C h E$ Inhibitory Activity}

The inhibitory activity of the novel compounds on human recombinant $\mathrm{AChE}$ and on human serum BChE (Sigma, Milan, Italy) was evaluated spectrophotometrically by the method of Ellman et al. [34]. The AChE stock solution was prepared by dissolving human recombinant AChE lyophilized powder in $0.1 \%$ Triton $\mathrm{X}-100 / 0.1 \mathrm{M}$ potassium phosphate, $\mathrm{pH}$ 8.0. The stock solution of human serum BChE was prepared by dissolving the lyophilized powder in aqueous $0.1 \%$ gelatine. The stock solutions of the novel compounds $(1 \mathrm{mM})$ were prepared in $\mathrm{MeOH}$. The assay solution contained $340 \mu \mathrm{M}$ 5,5'-dithiobis(2-nitrobenzoic acid) (DTNB), $0.02 \mathrm{unit} / \mathrm{mL}$ hAChE or hBChE, and $550 \mu \mathrm{M}$ substrate (acetylthiocholine iodide or butyrylthiocholine iodide, for AChE and BChE, respectively), in $0.1 \mathrm{M}$ potassium phosphate, $\mathrm{pH}$ 8.0. Assay solutions with and without inhibitor were preincubated at $37^{\circ} \mathrm{C}$ for $20 \mathrm{~min}$, and then the substrate was added. Blank solutions containing all components except the enzymes were prepared in parallel to correct for non-enzymatic hydrolysis of the substrate. Initial rate assays were performed at $37{ }^{\circ} \mathrm{C}$ with a Jasco V-530 double beam spectrophotometer. At least five increasing concentrations of the inhibitors, which produced $20-80 \%$ inhibition of the enzymatic activity, were assayed. $\mathrm{IC}_{50}$ values were calculated using Microcal Origin 3.5 software (Microcal Software, Inc., Darmstadt, Germany).

\subsubsection{PAMPA-BBB Assay}

The brain permeability $(\mathrm{Pe})$ of the target compounds was determined in vitro using the parallel artificial membrane permeation assay for blood-brain barrier penetration described by Di et al. [41], employing a lipid extract of porcine brain membrane in a mixture of PBS/EtOH 70:30. Assay validation was implemented by comparing the experimental and reported $P e$ values of a set of fourteen commercial drugs (Table 2). A good correlation was obtained: $P e(\exp )=1.5087 \mathrm{Pe}($ lit $)-0.8974$ $\left(R^{2}=0.9296\right)$. From this equation, and taking into account the limits established by Di et al. for BBB permeation, the following ranges of permeability were established: high BBB permeation (CNS+): $P e\left(10^{-6} \mathrm{~cm} \mathrm{~s}^{-1}\right)>5.13$; low BBB permeation (CNS-): $P e\left(10^{-6} \mathrm{~cm} \mathrm{~s}^{-1}\right)<2.12$, and uncertain BBB permeation $\left(\mathrm{CNS} \pm\right.$ ): $5.13>\mathrm{Pe}\left(10^{-6} \mathrm{~cm} \mathrm{~s}^{-1}\right)>2.12$. 
Table 2. Experimental and reported BBB permeability $\left(P e 10^{-6} \mathrm{~cm} \mathrm{~s}^{-1}\right)$ values of the commercial drugs used for assay validation.

\begin{tabular}{ccc}
\hline Compound & Reported $\boldsymbol{P e}^{\mathbf{1}}$ & Experimental $\boldsymbol{P e}^{\mathbf{2}}$ \\
\hline Cimetidine & 0.0 & $0.7 \pm 0.1$ \\
Lomefloxacin & 1.1 & $0.8 \pm 0.1$ \\
Norfloxazin & 0.1 & $0.9 \pm 0.1$ \\
Ofloxazin & 0.8 & $1.0 \pm 0.1$ \\
Hydrocortisone & 1.9 & $1.4 \pm 0.1$ \\
Piroxicam & 2.5 & $1.8 \pm 0.1$ \\
Clonidine & 5.3 & $6.5 \pm 0.1$ \\
Corticosterone & 5.1 & $6.7 \pm 0.1$ \\
Imipramine & 13.0 & $12.3 \pm 0.1$ \\
Promazine & 8.8 & $13.8 \pm 0.3$ \\
Progesterone & 9.3 & $16.8 \pm 0.3$ \\
Desipramine & 12.0 & $17.8 \pm 0.1$ \\
Testosterone & 17.0 & $24.7 \pm 1.4$ \\
Verapamil & 16.0 & $25.4 \pm 1.6$ \\
\hline [41]; ${ }^{2}$ Values are expressed as the mean \pm SD of three independent experiments.
\end{tabular}

\subsection{Structural Biology}

\subsubsection{Crystallization and Data Collection}

TcAChE (12 $\left.\mathrm{mg} \mathrm{mL}^{-1}\right)$, purified according to Sussman et al. [48], was crystallized by the hanging-drop vapor diffusion method. Equal volumes $(1 \mu \mathrm{L})$ of protein solution and of $30 \%$ PEG 200/50 mM MES, pH 6.0, were mixed at $4{ }^{\circ} \mathrm{C}$. Crystals appeared within a few days, and were harvested after 2-3 weeks. The crystals were then soaked in the above-mentioned mother liquor complemented with the candidate compounds at a concentration of $1 \mathrm{mM}$, for at least $12 \mathrm{~h}$. All data were collected on the ID30A1 beamline of the European Synchrotron Radiation Facility (ESRF, Grenoble, France) from crystals flash-frozen and stored in liquid nitrogen until utilized.

\subsubsection{Data Processing and Refinement}

Diffraction images were indexed and integrated using XDS, and intensities were further scaled and merged with XSCALE. Phases were retrieved using the molecular replacement technique with PHASER. PDB entry $2 \mathrm{Xi} 4$ served as the starting model of TcAChE that was employed. All data were obtained from orthorhombic TcAChE crystals, and two subunits were placed in the asymmetric unit of all complex structures. The model was refined by iterative cycles of refinement with phenix.refine and model building using Coot. With phenix.refine, refinement of atomic positions and individual isotropic temperature factors was performed in real space (against the experimental electron density map) and in reciprocal space (against experimental intenstities). All ligand topologies were generated with the PRODRG server and their occupancies were refined during the final cycles of refinement. The coordinates and structure factors have been deposited in the Protein Data Bank under accession code $6 \mathrm{FOT}, 6 \mathrm{FOU}$, and 6FOV, for structures of complexes of 5, 6 and 16, respectively, with TcAChE. Data collection and refinement statistics are presented in Table 3. 
Table 3. Data collection and refinement statistics. ${ }^{1}$

\begin{tabular}{|c|c|c|c|}
\hline & 5 & 6 & 16 \\
\hline Resolution range $(\AA)$ & $44.04-1.79(1.854-1.79)$ & $46.03-1.82(1.82-1.89)$ & $45.7-1.9(1.968-1.9)$ \\
\hline Space group & P 212121 & P 212121 & P 212121 \\
\hline Unit cell $(\AA)$ & 91.44106 .61150 .53 & 91.74106 .44150 .68 & 91.82106 .81151 .67 \\
\hline Total reflections & $634,220(58,489)$ & $642,785(63,116)$ & $1,072,187(87,007)$ \\
\hline Unique reflections & $138,453(13,737)$ & $130,469(12,879)$ & $117,742(11,618)$ \\
\hline Multiplicity & $4.6(4.3)$ & $4.9(4.9)$ & $7.7(7.5)$ \\
\hline Completeness (\%) & $99.66(99.75)$ & $98.4(91.8)$ & $99.71(99.38)$ \\
\hline Mean I/sigma(I) & $12.9(1.5)$ & $12.6(1.6)$ & $8.8(1.0)$ \\
\hline Wilson B-factor $\left(\AA^{2}\right)$ & 24.63 & 24.09 & 29.21 \\
\hline R-merge & $0.067(0.943)$ & $0.075(1.054)$ & $0.128(1.286)$ \\
\hline $\mathrm{CC} 1 / 2$ & $0.998(0.686)$ & $0.999(0.719)$ & $0.998(0.588)$ \\
\hline Reflections used in refinement & $138,303(13,721)$ & $159,670(14,805)$ & $117,502(11,589)$ \\
\hline Reflections used for R-free & $6854(681)$ & $7990(773)$ & $5876(580)$ \\
\hline R-work & $0.1797(0.3422)$ & $0.1896(0.3100)$ & $0.1880(0.3357)$ \\
\hline R-free & $0.2125(0.3788)$ & $0.2193(0.3114)$ & $0.2177(0.3411)$ \\
\hline Number of non-hydrogen atoms & 9962 & 9719 & 9640 \\
\hline macromolecules & 8591 & 8583 & 8564 \\
\hline ligands & 321 & 153 & 163 \\
\hline solvent & 1040 & 983 & 916 \\
\hline Protein residues & 1067 & 1064 & 1068 \\
\hline RMS (bonds) $(\AA)$ & 0.006 & 0.007 & 0.007 \\
\hline RMS (angles) $\left(^{\circ}\right)$ & 0.88 & 0.86 & 0.88 \\
\hline Ramachandran favored (\%) & 96.29 & 96.30 & 96.03 \\
\hline Ramachandran allowed (\%) & 3.71 & 3.70 & 3.88 \\
\hline Ramachandran outliers (\%) & 0.00 & 0.00 & 0.09 \\
\hline Rotamer outliers (\%) & 0.74 & 1.40 & 2.40 \\
\hline Clashscore & 4.19 & 3.67 & 3.45 \\
\hline Average B-factor $\left(\AA^{2}\right)$ & 31.03 & 31.94 & 35.77 \\
\hline macromolecules & 29.49 & 30.88 & 34.72 \\
\hline ligands & 45.26 & 45.93 & 50.66 \\
\hline solvent & 39.32 & 38.98 & 42.98 \\
\hline
\end{tabular}

${ }^{1}$ Statistics for the highest-resolution shell are shown in parentheses.

\section{Conclusions}

Starting from the chemical structures of the potent brain-permeable AChE inhibitors tacrine, 6-chlorotacrine, and huprine $Y$, which are of interest in the context of Alzheimer's disease treatment, we have designed and synthesized two series of derivatives of increased polarity with the aim of precluding their penetration into the central nervous system, thus confining their anticholinesterase action to the peripheral level for potential therapeutic use against myasthenia gravis. In one of the series, we increased polarity by the classic approach based on quaternization by alkylation of a nucleophilic nitrogen atom, which produced the quinolinium derivatives of tacrine, 6-chlorotacrine, and huprine Y 4-6. In a second series, we increased polarity by installation of a 1,2,3-triazole ring within a side chain at position 9 of tacrine and 6-chlorotacrine (compounds 9 and 10), and of an additional polyphenol-like moiety in compounds 15 and 16. In general, these structural changes lead to decreased $\mathrm{AChE}$ and $\mathrm{BChE}$ inhibitory activities relative to the parent compounds, with the exception of the triazole-containing compound 16, which is a more potent $\mathrm{AChE}$ and BChE inhibitor than the parent 6-chlorotacrine, likely as a result of multi-site binding within the active-site gorge of the enzyme, as confirmed by the crystal structure of its complex with TcAChE. Despite their lower anticholinesterase potencies compared with the parent compounds, most of the novel derivatives are clearly more potent than pyridostigmine, the preferred drug for symptomatic treatment of myasthenia gravis, and have been found to display low brain permeability values in the PAMPA-BBB assay, thus possessing favorable pharmacodynamic and pharmacokinetic attributes for the intended use against myasthenia gravis. 
Acknowledgments: This work was supported by Ministerio de Economía y Competitividad (MINECO) (SAF2014-57094-R), Generalitat de Catalunya (GC) (2014SGR52), the Agence Nationale de la Recherche (ANR) (ANR-12-BS07-0008-01), the France Alzheimer Foundation (FA-AAP-2013-65-101349 to J.-P.C.) and the Italian Ministry of Education, University and Research - MIUR. This work was partially supported by INSA Rouen, Rouen-Normandie University, Centre National de la Recherche Scientifique (CNRS), Région Haute-Normandie (CRUNCh network), and the Labex SynOrg (ANR-11-LABX-0029). Fellowships from IBUB to C.G. and from ANR to M.C.-B. are gratefully acknowledged. We thank Lilly Toker for preparation of the purified TcAChE.

Author Contributions: D.M.-T., P.-Y.R., and J.-P.C. conceived and designed the experiments; D.M.-T., P.-Y.R., and L.J. supervised the synthetic work; C.G. and M.C.-B. performed the synthetic work; J.-P.C. and I.S. supervised the structural biology work; N.C. performed the structural biology work; M.B., B.P., and M.V.C. performed the in vitro biological profiling; all authors analyzed the data; D.M.-T., P.-Y.R., J.-P.C., L.J., and N.C. wrote manuscript.

Conflicts of Interest: The authors declare no conflict of interest.

\section{References}

1. Gilhus, N.E.; Verschuuren, J.J. Myasthenia gravis: Subgroup classification and therapeutic strategies. Lancet Neurol. 2015, 14, 1023-1036. [CrossRef]

2. Melzer, N.; Ruck, T.; Fuhr, P.; Gold, R.; Hohlfeld, R.; Marx, A.; Melms, A.; Tackenberg, B.; Schalke, B.; Schneider-Gold, C.; et al. Clinical features, pathogenesis, and treatment of myasthenia gravis: A supplement to the guidelines of the German Neurological Society. J. Neurol. 2016, 263, 1473-1494. [CrossRef] [PubMed]

3. Conti-Fine, B.M.; Milani, M.; Kaminski, H.J. Myasthenia gravis: Past, present, and future. J. Clin. Investig. 2006, 116, 2843-2854. [CrossRef] [PubMed]

4. Carr, A.S.; Cardwell, C.R.; McCarron, P.O.; McConville, J. A systematic review of population based epidemiological studies in Myasthenia Gravis. BMC Neurol. 2010, 10, 46. [CrossRef] [PubMed]

5. Binks, S.; Vincent, A.; Palace, J. Myasthenia gravis: A clinical-immunological update. J. Neurol. 2016, 263, 826-834. [CrossRef] [PubMed]

6. Brenner, T.; Nizri, E.; Irony-Tur-Sinai, M.; Hamra-Amitay, Y.; Wirguin, I. Acetylcholinesterase inhibitors and cholinergic modulation in Myasthenia Gravis and neuroinflammation. J. Neuroimmunol. 2008, 201-202, 121-127. [CrossRef] [PubMed]

7. Punga, A.R.; Stålberg, E. Acetylcholinesterase inhibitors in myasthenia gravis: To be or not to be? Muscle Nerve 2009, 39, 724-728. [CrossRef] [PubMed]

8. Alkhawajah, N.M.; Oger, J. Treatment of myasthenia gravis in the aged. Drugs Aging 2015, 32, 689-697. [CrossRef] [PubMed]

9. Komloova, M.; Musilek, K.; Dolezal, M.; Gunn-Moore, F.; Kuca, K. Structure-activity relationship of quaternary acetylcholinesterase inhibitors-Outlook for early myasthenia gravis treatment. Curr. Med. Chem. 2010, 17, 1810-1824. [CrossRef] [PubMed]

10. Lindovský, J.; Petrov, K.; KrǔšeK, J.; Reznik, V.S.; Nikolsky, E.E.; Vyskočil, F. Effect of tissue-specific acetylcholinesterase inhibitor C-547 on $\alpha 3 \beta 4$ and $\alpha \beta \varepsilon \delta$ acetylcholine receptors in COS cells. Eur. J. Pharmacol. 2012, 688, 22-26. [CrossRef] [PubMed]

11. Clark, J.K.; Cowley, P.; Muir, A.W.; Palin, R.; Pow, E.; Prosser, A.B.; Taylor, R.; Zhang, M.Q. Quaternary salts of E2020 analogues as acetylcholinesterase inhibitors for the reversal of neuromuscular block. Bioorg. Med. Chem. Lett. 2002, 12, 2565-2568. [CrossRef]

12. Palin, R.; Clark, J.K.; Cowley, P.; Muir, A.W.; Pow, E.; Prosser, A.B.; Taylor, R.; Zhang, M.Q. Novel piperidinium and pyridinium agents as water-soluble acetylcholinesterase inhibitors for the reversal of neuromuscular blockade. Bioorg. Med. Chem. Lett. 2002, 12, 2569-2572. [CrossRef]

13. Musilek, K.; Komloova, M.; Zavadova, V.; Holas, O.; Hrabinova, M.; Pohanka, M.; Dohnal, V.; Nachon, F.; Dolezal, M.; Kuca, K.; et al. Preparation and in vitro screening of symmetrical bispyridinium cholinesterase inhibitors bearing different connecting linkage-Initial study for Myasthenia gravis implications. Bioorg. Med. Chem. Lett. 2010, 20, 1763-1766. [CrossRef] [PubMed]

14. Komloova, M.; Musilek, K.; Horova, A.; Holas, O.; Dohnal, V.; Gunn-Moore, F.; Kuca, K. Preparation, in vitro screening and molecular modelling of symmetrical bis-quinolinium cholinesterase inhibitors-Implications for early Myasthenia gravis treatment. Bioorg. Med. Chem. Lett. 2011, 21, 2505-2509. [CrossRef] [PubMed] 
15. Musilek, K.; Komloova, M.; Holas, O.; Hrabinova, M.; Pohanka, M.; Dohnal, V.; Nachon, F.; Dolezal, M.; Kuca, K. Preparation and in vitro screening of symmetrical bis-isoquinolinium cholinesterase inhibitors bearing various connecting linkage-Implications for early Myasthenia gravis treatment. Eur. J. Med. Chem. 2011, 46, 811-818. [CrossRef] [PubMed]

16. Mary, A.; Renko, D.Z.; Guillou, C.; Thal, C. Potent acetylcholinesterase inhibitors: Design, synthesis, and structure-activity relationships of bis-interacting ligands in the galanthamine series. Bioorg. Med. Chem. 1998, 6, 1835-1850. [CrossRef]

17. Freeman, S.E.; Dawson, R.M. Tacrine: A pharmacological review. Prog. Neurobiol. 1991, 36, $257-277$. [CrossRef]

18. Gregor, V.E.; Emmerling, M.R.; Lee, C.; Moore, C.J. The synthesis and in vitro acetylcholinesterase and butyrylcholinesterase inhibitory activity of tacrine $\left(\right.$ Cognex $\left.{ }^{\circledR}\right)$ derivatives. Bioorg. Med. Chem. Lett. 1992, 2, 861-864. [CrossRef]

19. Camps, P.; El Achab, R.; Görbig, D.M.; Morral, J.; Muñoz-Torrero, D.; Badia, A.; Baños, J.E.; Vivas, N.M.; Barril, X.; Orozco, M.; et al. Synthesis, in vitro pharmacology, and molecular modeling of very potent tacrine-huperzine A hybrids as acetylcholinesterase inhibitors of potential interest for the treatment of Alzheimer's disease. J. Med. Chem. 1999, 42, 3227-3242. [CrossRef] [PubMed]

20. Camps, P.; El Achab, R.; Morral, J.; Muñoz-Torrero, D.; Badia, A.; Baños, J.E.; Vivas, N.M.; Barril, X.; Orozco, M.; Luque, F.J. New tacrine-huperzine A hybrids (huprines): Highly potent tight-binding acetylcholinesterase inhibitors of interest for the treatment of Alzheimer's disease. J. Med. Chem. 2000, 43, 4657-4666. [CrossRef] [PubMed]

21. Camps, P.; Cusack, B.; Mallender, W.D.; El Achab, R.; Morral, J.; Muñoz-Torrero, D.; Rosenberry, T.L. Huprine $\mathrm{X}$ is a novel high-affinity inhibitor of acetylcholinesterase that is of interest for treatment of Alzheimer's disease. Mol. Pharmacol. 2000, 57, 409-417. [PubMed]

22. Huisgen, R. 1,3-Dipolar cycloaddition-Introduction, survey, mechanism. In 1,3-Dipolar Cycloaddition Chemistry; Padwa, A., Ed.; Wiley: New York, NY, USA, 1984; Volume 1, pp. 1-176.

23. Kolb, H.C.; Sharpless, K.B. The growing impact of click chemistry on drug discovery. Drug Discov. Today 2003, 8, 1128-1137. [CrossRef]

24. Bourne, Y.; Kolb, H.C.; Radić, Z.; Sharpless, K.B.; Taylor, P.; Marchot, P. Freeze-frame inhibitor captures acetylcholinesterase in a unique conformation. Proc. Natl. Acad. Sci. USA 2004, 101, 1449-1454. [CrossRef] [PubMed]

25. Lewis, W.G.; Green, L.G.; Grynszpan, F.; Radić, Z.; Carlier, P.R.; Taylor, P.; Finn, M.G.; Sharpless, K.B. Click chemistry in situ: Acetylcholinesterase as a reaction vessel for the selective assembly of a femtomolar inhibitor from an array of building blocks. Angew. Chem. Int. Ed. 2002, 41, 1053-1057. [CrossRef]

26. Oueis, E.; Santoni, G.; Ronco, C.; Syzgantseva, O.; Tognetti, V.; Joubert, L.; Romieu, A.; Weik, M.; Jean, L.; Sabot, C.; et al. Reaction site-driven regioselective synthesis of AChE inhibitors. Org. Biomol. Chem. 2014, 12, 156-161. [CrossRef] [PubMed]

27. Oueis, E.; Sabot, C.; Renard, P.Y. New insights into the kinetic target-guided synthesis of protein ligands. Chem. Commun. 2015, 51, 12158-12169. [CrossRef] [PubMed]

28. Sussman, J.L.; Harel, M.; Frolow, F.; Oefner, C.; Goldman, A.; Toker, L.; Silman, I. Atomic structure of acetylcholinesterase from Torpedo californica: A prototypic acetylcholine-binding protein. Science 1991, 253, 872-879. [CrossRef] [PubMed]

29. Galanakis, D.; Davis, C.A.; Herrero, B.D.R.; Ganellin, C.R.; Dunn, P.M.; Jenkinson, D.H. Synthesis and structure-activity relationships of dequalinium analogues as $\mathrm{K}^{+}$channel blockers. Investigations on the role of the charged heterocycle. J. Med. Chem. 1995, 38, 595-606. [CrossRef] [PubMed]

30. Manetsch, R.; Krasiński, A.; Radić, Z.; Raushel, J.; Taylor, P.; Sharpless, K.B.; Kolb, H.C. In situ click chemistry: Enzyme inhibitors made to their own specifications. J. Am. Chem. Soc. 2004, 126, 12809-12818. [CrossRef] [PubMed]

31. Guo, Y.; Liu, H.; Xu, M. Synthesis and bioactivity of novel tacrine-indole hybrids by microwave-assisted Huisgen [3 + 2] cycloaddition reaction. Chin. J. Org. Chem. 2012, 32, 413-419. [CrossRef] 
32. Camps, P.; Formosa, X.; Galdeano, C.; Gómez, T.; Muñoz-Torrero, D.; Scarpellini, M.; Viayna, E.; Badia, A.; Clos, M.V.; Camins, A.; et al. Novel donepezil-based inhibitors of acetyl- and butyrylcholinesterase and acetylcholinesterase-induced $\beta$-amyloid aggregation. J. Med. Chem. 2008, 51, 3588-3598. [CrossRef] [PubMed]

33. Cole, A.G.; Metzger, A.; Brescia, M.-R.; Qin, L.-Y.; Appell, K.C.; Brain, C.T.; Hallett, A.; Ganju, P.; Denholm, A.A.; Wareing, J.R.; et al. Sulfonamido-aryl ethers as bradykinin B1 receptor antagonists. Bioorg. Med. Chem. Lett. 2009, 19, 119-122. [CrossRef] [PubMed]

34. Ellman, G.L.; Courtney, K.D.; Andres, V., Jr.; Featherstone, R.M. A new and rapid colorimetric determination of acetylcholinesterase activity. Biochem. Pharmacol. 1961, 7, 88-95. [CrossRef]

35. Dvir, H.; Wong, D.M.; Harel, M.; Barril, X.; Orozco, M.; Luque, F.J.; Muñoz-Torrero, D.; Camps, P.; Rosenberry, T.L.; Silman, I.; et al. 3D Structure of Torpedo californica acetylcholinesterase complexed with huprine X at 2.1 Å resolution: Kinetic and molecular dynamics correlates. Biochemistry 2002, 41, 2970-2981. [CrossRef] [PubMed]

36. Savini, L.; Gaeta, A.; Fattorusso, C.; Catalanotti, B.; Campiani, G.; Chiasserini, L.; Pellerano, C.; Novellino, E.; McKissic, D.; Saxena, A. Specific targeting of acetylcholinesterase and butyrylcholinesterase recognition sites. Rational design of novel, selective, and highly potent cholinesterase inhibitors. J. Med. Chem. 2003, 46, 1-4. [CrossRef] [PubMed]

37. Elsinghorst, P.W.; Cieslik, J.S.; Mohr, K.; Tränkle, C.; Gütschow, M. First gallamine-tacrine hybrid: Design and characterization at cholinesterases and the $\mathrm{M}_{2}$ muscarinic receptor. J. Med. Chem. 2007, 50, 5685-5695. [CrossRef] [PubMed]

38. Kharlamova, A.D.; Lushchekina, S.V.; Petrov, K.A.; Kots, E.D.; Nachon, F.; Villard-Wandhammer, M.; Zueva, I.V.; Krejci, E.; Reznik, V.S.; Zobov, V.V.; et al. Slow-binding inhibition of acetylcholinesterase by an alkylammonium derivative of 6-methyluracil: Mechanism and possible advantages for myasthenia gravis treatment. Biochem. J. 2016, 473, 1225-1236. [CrossRef] [PubMed]

39. Petrov, K.A.; Girard, E.; Nikitashina, A.D.; Colasante, C.; Bernard, V.; Nurullin, L.; Leroy, J.; Samigullin, D.; Colak, O.; Nikolsky, E.; et al. Schwann cells sense and control acetylcholine spillover at the neuromuscular junction by $\alpha 7$ nicotinic receptors and butyrylcholinesterase. J. Neurosci. 2014, 34, 11870-11883. [CrossRef] [PubMed]

40. Lee, M.; Beeson, D.; Palace, J. Therapeutic strategies for congenital myasthenic syndromes. Ann. N. Y. Acad. Sci. 2018, 1412, 129-136. [CrossRef] [PubMed]

41. Di, L.; Kerns, E.H.; Fan, K.; McConnell, O.J.; Carter, G.T. High throughput artificial membrane permeability assay for blood-brain barrier. Eur. J. Med. Chem. 2003, 38, 223-232. [CrossRef]

42. Morphy, R.; Rankovic, Z. The physicochemical challenges of designing multiple ligands. J. Med. Chem. 2006, 49, 4961-4970. [CrossRef] [PubMed]

43. Nepovimova, E.; Uliassi, E.; Korabecny, J.; Peña-Altamira, L.E.; Samez, S.; Pesaresi, A.; Garcia, G.E.; Bartolini, M.; Andrisano, V.; Bergamini, C.; et al. Multitarget drug design strategy: Quinone-tacrine hybrids designed to block amyloid- $\beta$ aggregation and to exert anticholinesterase and antioxidant effects. J. Med. Chem. 2014, 57, 8576-8589. [CrossRef] [PubMed]

44. Liebschner, D.; Afonine, P.V.; Moriarty, N.W.; Poon, B.K.; Sobolev, O.V.; Terwilliger, T.C.; Adams, P.D. Polder maps: Improving OMIT maps by excluding bulk solvent. Acta Cryst. 2017, D73, 148-157. [CrossRef] [PubMed]

45. Desiraju, G.R.; Steiner, T. The Weak Hydrogen Bond in Structural Chemistry and Biology; Oxford University Press: Oxford, UK, 1999.

46. Nachon, F.; Carletti, E.; Ronco, C.; Trovaslet, M.; Nicolet, Y.; Jean, L.; Renard, P.-Y. Crystal structures of human cholinesterases in complex with huprine $\mathrm{W}$ and tacrine: Elements of specificity for anti-Alzheimer's drugs targeting acetyl- and butyryl-cholinesterase. Biochem. J. 2013, 453, 393-399. [CrossRef] [PubMed]

47. Ronco, C.; Carletti, E.; Colletier, J.-P.; Weik, M.; Nachon, F.; Jean, L.; Renard, P.-Y. Huprine derivatives as sub-nanomolar human acetylcholinesterase inhibitors: From rational design to validation by $\mathrm{X}$-ray crystallography. ChemMedChem 2012, 7, 400-405. [CrossRef] [PubMed] 
48. Sussman, J.L.; Harel, M.; Frolow, F.; Varon, L.; Toker, L.; Futerman, A.H.; Silman, I. Purification and crystallization of a dimeric form of acetylcholinesterase from Torpedo californica subsequent to solubilization with phosphatidylinositol-specific phospholipase. J. Mol. Biol. 1988, 203, 821-823. [CrossRef]

Sample Availability: Samples of the compounds 4-6, 9, 10, and 13 are available from the authors.

(C) 2018 by the authors. Licensee MDPI, Basel, Switzerland. This article is an open access article distributed under the terms and conditions of the Creative Commons Attribution (CC BY) license (http:/ / creativecommons.org/licenses/by/4.0/). 